OPEN ACCESS

Edited by:

Arun Saini,

Texas Children's Hospital,

United States

Reviewed by:

Martin Kneyber,

University Medical Center

Groningen, Netherlands

Dincer Riza Yildizdas,

Çukurova University, Turkey

Thorsten Haas,

University Children's Hospital

Zurich, Switzerland

Melissa Cushing,

NewYork-Presbyterian, United States

*Correspondence:

Gemma Louise Crighton

gemma.crighton@rch.org.au

Specialty section:

This article was submitted to

Pediatric Critical Care,

a section of the journal

Frontiers in Pediatrics

Received: 30 December 2020

Accepted: 09 March 2021

Published: 21 April 2021

Citation:

Crighton GL and Huisman EJ (2021)

Pediatric Fibrinogen PART

II-Overview of Indications for

Fibrinogen Use in Critically III Children.

Front. Pediatr. 9:647680.

doi: 10.3389/fped.2021.647680

\section{Pediatric Fibrinogen PART II-Overview of Indications for Fibrinogen Use in Critically III Children}

\author{
Gemma Louise Crighton ${ }^{1 *}$ and Elise J. Huisman ${ }^{2,3,4}$ \\ ${ }^{1}$ Department of Hematology, Royal Children's Hospital, Melbourne, VIC, Australia, ${ }^{2}$ Department of Hematology, Erasmus \\ MC-Sophia Children's Hospital, Rotterdam, Netherlands, ${ }^{3}$ Department of Clinical Chemistry and Blood Transfusion, Erasmus \\ MC, Rotterdam, Netherlands, ${ }^{4}$ Department of Transfusion Medicine, Sanquin Blood Supply, Amsterdam, Netherlands
}

Bleeding is frequently seen in critically ill children and is associated with increased morbidity and mortality. Fibrinogen is an essential coagulation factor for hemostasis and hypofibrinogenemia is an important risk factor for bleeding in pediatric and adult settings. Cryoprecipitate and fibrinogen concentrate are often given to critically ill children to prevent bleeding and improve fibrinogen levels, especially in the setting of surgery, trauma, leukemia, disseminated intravascular coagulopathy, and liver failure. The theoretical benefit of fibrinogen supplementation to treat hypofibrinogenemia appears obvious, yet the evidence to support fibrinogen supplementation in children is sparce and clinical indications are poorly defined. In addition, it is unknown what the optimal fibrinogen replacement product is in children and neonates or what the targets of treatment should be. As a result, there is considerable variability in practice. In this article we will review the current pediatric and applicable adult literature with regard to the use of fibrinogen replacement in different pediatric critical care contexts. We will discuss the clinical indications for fibrinogen supplementation in critically ill children and the evidence to support their use. We summarize by highlighting current knowledge gaps and areas for future research.

Keywords: fibrinogen, children, hypofibrinogenemia, cryoprecipitate, fibrinogen concentrate, bleeding, hyperfibrinolysis

\section{INTRODUCTION}

\section{Bleeding in Critically III Children}

Bleeding is a common complication observed in critically ill children and appears to be multifactorial (1). In children admitted to the pediatric intensive care unit (PICU), clinically significant bleeding is reported to occur in $\sim 10 \%$ with higher rates reported in those receiving mechanical circulatory support (1-3). Bleeding is associated with adverse outcomes including longer PICU stays, increased vasopressor support, increased red cell transfusions $(1,2)$ and in children requiring extracorporeal membrane oxygenation (ECMO) increased mortality (3).

\section{Hypofibrinogenemia in Critically III Children}

Fibrinogen (Factor I) is an essential hemostatic protein, with a key role in all aspects of normal hemostasis $(4,5)$. In critically ill children, fibrinogen has not been identified as an independent risk factor for bleeding. Studies looking at risk factors for bleeding in critically ill children have 
either not evaluated fibrinogen levels (1) or found the opposite, namely that fibrinogen levels are higher in critically ill children with bleeding (2). This finding most likely reflects that fibrinogen is an acute phase reactant and therefore may be elevated in the critical care context, in the context of sepsis, infection, or inflammation (6). Hypofibrinogenemia has been identified as an important risk factor for bleeding in other pediatric and adult settings (7-9). It is therefore important to appreciate a low fibrinogen level and recognize its potential contribution to bleeding.

See Pediatric Fibrinogen Part I-Pitfalls in Fibrinogen Evaluation and Use of Fibrinogen Replacement Products for further information about the diagnostic tools used to measure fibrinogen in critically ill children and the available fibrinogen replacement products.

\section{Hypofibrinogenemia in Critically III Children}

Hypofibrinogenemia in the PICU is most commonly acquired, or secondary to an underlying process. See Figure 1. It may result from:

A) Reduced/absent or abnormal fibrinogen synthesis as seen in severe liver disease (10) or, in the rare instance of congenital fibrinogen disorders.

B) Fibrinogen loss exceeding fibrinogen production for example, during massive blood loss (11).

C) Hyperfibrinolysis, a condition where fibrinolytic activity exceeds fibrin formation, which may be observed in trauma (12), post cardiopulmonary bypass (CPB), with extracorporeal membrane oxygenation (ECMO) $(9,13)$ and in disseminated intravascular coagulopathy (DIC) (14). See Figure 1.

Cryoprecipitate and fibrinogen concentrate are most commonly used to provide fibrinogen supplementation, and both effectively restore fibrinogen levels (15-18). They may be given to provide fibrinogen replacement during active bleeding or as prophylaxis to prevent bleeding. A prospective study of cryoprecipitate use in England, found that most cryoprecipitate given to children was for prophylactic, rather than therapeutic indications, specifically in the context of pediatric cardiac surgery, critical care, or the hematology/oncology setting (19).

\section{THE CRITICAL FIBRINOGEN LEVEL}

There are a number of the age-related differences in the hemostatic systems including fibrinogen and fibrinolysis between neonates and older children and adults $(20,21)$. The critical fibrinogen threshold level and the risk of bleeding is debated in children of all ages.

Nevertheless, it is obvious that there is a strong association between fibrinogen level and bleeding severity in individuals with congenital fibrinogen deficiency, with bleeding rarely reported at fibrinogen levels $>100 \mathrm{mg} / \mathrm{dL}$ (22). The International Council for Standardization in Hematology considers a fibrinogen level of $50-200 \mathrm{mg} / \mathrm{dL}$ to be a critical test result but recognizes the overlap with normal references ranges; a result of $150 \mathrm{mg} / \mathrm{dL}$, may be normal or critical depending on the clinical context
(23). In the adult surgical setting a fibrinogen level of $<150$ $200 \mathrm{mg} / \mathrm{dL}$, increases the risk of perioperative and postoperative bleeding tendency (7). Similarly in children undergoing cardiac surgery, post-CPB fibrinogen levels of $<150 \mathrm{mg} / \mathrm{dL}$ have been shown in both retrospective (9), and prospective (8) studies to be associated with increased rates of post-operative bleeding.

As a result, international clinical guidelines outlining pediatric fibrinogen replacement guidance also, having varying fibrinogen thresholds and targets. See Table 1.

In summary, fibrinogen is a key hemostatic protein and hypofibrinogenemia is an important risk factor for bleeding, but the critical threshold is debated. Fibrinogen levels need to be interpreted in their clinical context, e.g., a child's age, the presence of inflammation or active bleeding and any planned surgery.

\section{THE EVIDENCE BASE}

\section{Systematic Reviews and Randomized Controlled Trials}

There is a lack of high-quality evidence to support the prophylactic or therapeutic use of cryoprecipitate and fibrinogen concentrate in children (24-28).

Existing evidence comes from the 2018 Cochrane systematic review, which evaluated the efficacy and safety of fibrinogen concentrate, with respect to the primary outcomes of mortality and thromboembolic events, in addition to secondary bleeding outcomes (27). The review identified 22 randomized controlled trials (RCT)s $(n=1,535)$ looking at fibrinogen concentrate of which three were pediatric $(n=143)$ (27). On review of the trial settings, 15 of the 22 trials were conducted in the elective perioperative setting, three in the trauma setting, two in women with post-partum hemorrhage and one in the context of liver transplantation (27). Ten of the 22 trials looked at prophylactic fibrinogen indications, nine compared fibrinogen concentrate with placebo and one trial evaluated two different fibrinogen concentrate intervention points based on FIBTEM. The remaining 12 trials were therapeutic trials, eight compared fibrinogen concentrate with placebo, and four compared fibrinogen concentrate to an active comparator (fresh frozen plasma $[\mathrm{FFP}]$, cryoprecipitate, or platelets) (27). The systematic review was significantly limited by the quality of the data published; trials were conducted in heterogeneous clinical settings, with varying interventions, primary outcomes, and different time points for outcome analysis (27). Therefore, meta-analysis could not be performed. Study samples sizes were small (mean 70 participants [range 20-249]) and none of the studies were powered to detect harm or adverse events, limiting their generalizability to clinical practice. Nevertheless, the systematic review observed that fibrinogen supplementation may reduce a patient's risk of receiving a red cell transfusion when compared with placebo in both cardiac and non-cardiac settings. In addition, prophylactic fibrinogen concentrate may reduce post-operative bleeding (27).

Two other recent systematic reviews have evaluated fibrinogen replacement therapies and included pediatric studies $(26,28)$. The first systematic review evaluated the 


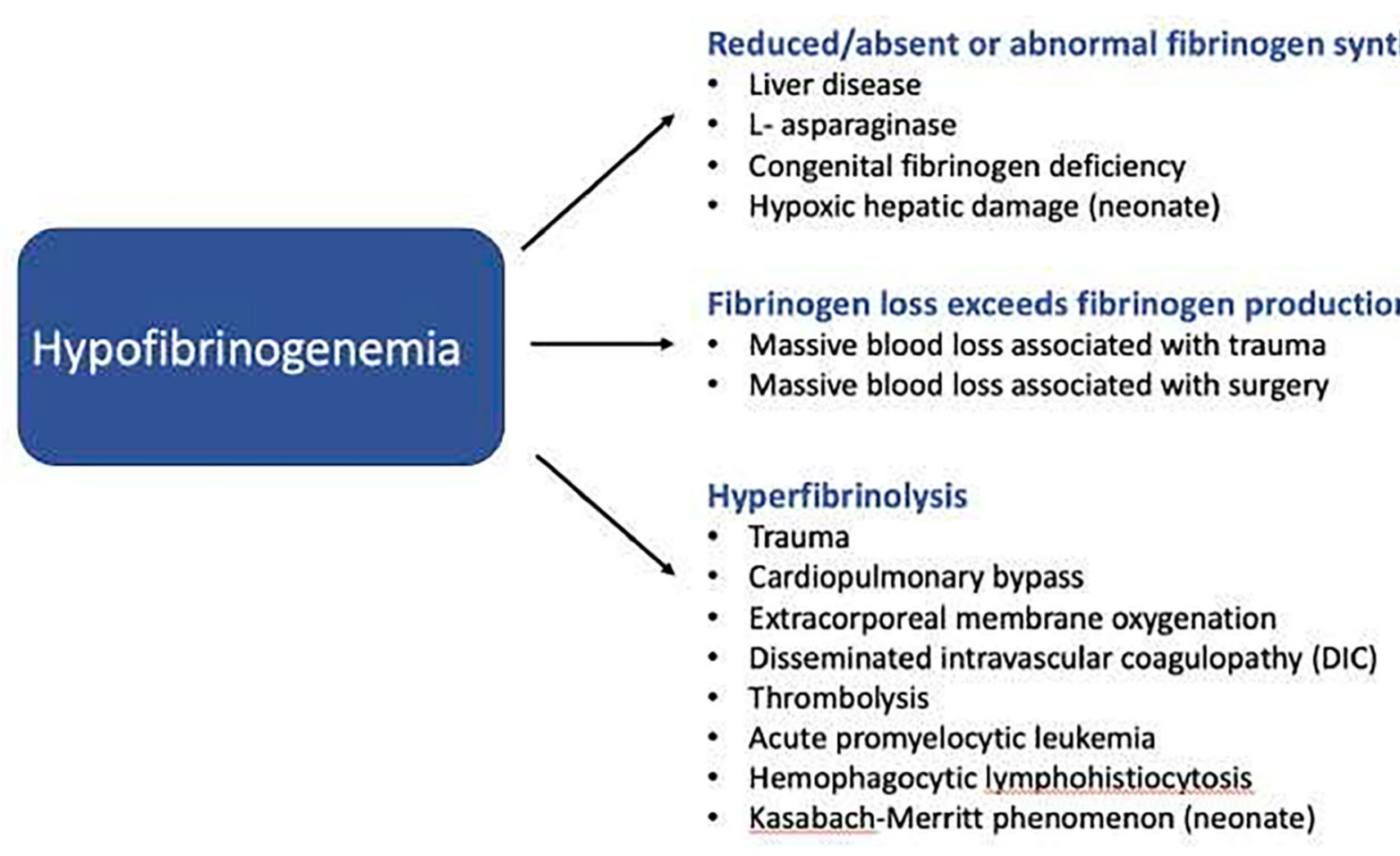

FIGURE 1 | Machanisms by which hypofibrinogenemia may develop in critically ill children.

use of fibrinogen concentrate in perioperative settings and identified 21 RCTs $(n=1,605)$ where fibrinogen concentrate was given either pre-emptively to prevent bleeding or to treat intraoperative bleeding (28). Two identified studies were performed in children $(n=114)(17,29)$. Overall there was considerable variability in the studies with respect to the patient populations, study designs, comparative arms, and outcomes, including bleeding rates. Only seven of the 12 trials that used fibrinogen concentrate to treat clinically relevant bleeding reported decreased bleeding tendency (28). The study authors rationalized that different study designs might explain the inconsistent results. They advocated for better-designed trials that evaluated patients with significant bleeding and hypofibrinogenemia (28).

The second systematic review evaluated the efficacy and safety of cryoprecipitate compared with fibrinogen in bleeding patients and identified one RCT $(n=63)$ conducted in children undergoing cardiac surgery and three observational studies that included adults. All studies were at high risk of bias and the authors concluded that it was not possible from the current evidence to recommend one fibrinogen replacement product over another (26).

From the systematic reviews and literature search, eight published pediatric RCTs $(n=616)(17,18,29-33)$ evaluating fibrinogen replacement in the surgical setting were identified for the purpose of this review. Of the eight RCTs, five are performed in the cardiac surgery setting (17, 18, 32-34), one in the adolescent scoliosis setting (30), one in infants undergoing craniofacial surgery (31), and the final study included both infants undergoing craniofacial surgery and adolescents undergoing scoliosis surgery (29). The details and results will be discussed further in the respective surgical settings and are presented in Table 2.

From the list of ongoing trials identified by the Cochrane systematic review (27), an additional RCT in children (sample size 30) undergoing cardiac surgery has completed recruitment and the results are awaited (35).

\section{Evidence Translated in Guidelines}

Whilst the evidence to support fibrinogen supplementation in children is sparse, guidance regarding fibrinogen supplementation has been included in a number of neonatal and pediatric transfusion guidelines $(24,25,36-38)$, as well as some adult-centric guidelines (36, 39-44). See Table 1 for more details. Transfusion guidance provided by national European blood transfusion guidelines differs, since cryoprecipitate is not available and instead, fibrinogen concentrate is used to treat acquired hypofibrinogenemia. There is, however, no consensus European statement or guideline that provides guidance about fibrinogen concentrate indications, thresholds and doses for fibrinogen replacement in neonates and children. Local European guidelines are often difficult to access since they are usually only written in their native language.

The decision to provide fibrinogen replacement to a child, should involve an evaluation a child's condition, the presence of active bleeding, in conjunction with the results of laboratory 
TABLE 1 | Guidance for pediatric fibrinogen replacement therapy from international guidelines.

\begin{tabular}{|c|c|c|c|}
\hline Guideline & $\begin{array}{l}\text { Type of guideline and } \\
\text { patient population }\end{array}$ & Transfusion guidance and indications & Dosing information \\
\hline \multicolumn{4}{|c|}{ Cryoprecipitate } \\
\hline \multirow[t]{2}{*}{$\mathrm{BSH}(1)$} & $\begin{array}{l}\text { Neonatal and pediatric } \\
\text { specific transfusion } \\
\text { guideline }\end{array}$ & $\begin{array}{l}\text { Recommendations } \\
\text { - Prophylactic cryoprecipitate should not be routinely administered to } \\
\text { non-bleeding children with decreased fibrinogen including prior to surgery } \\
\text { - Cryoprecipitate should not be used for congenital hypofibrinogenemia } \\
\text { unless fibrinogen concentrate is unavailable } \\
\text { - Cryoprecipitate may be considered for fibrinogen }<100 \mathrm{mg} / \mathrm{dL} \text { for surgery } \\
\text { at risk of significant bleeding or to critical sites } \\
\text { - In the setting of DIC-cryoprecipitate may be given if fibrinogen is }<100 \\
\text { mg/dL despite FFP, or in conjunction with FFP for very low or rapidly } \\
\text { falling fibrinogen } \\
\text { - Clinically significant bleeding following CPB and fibrinogen }<150 \mathrm{mg} / \mathrm{dL} \text {, } \\
\text { specific component replacement may be warranted } \\
\text { Practice Point } \\
\text { In patients with critical bleeding - early use of FFP, platelets and } \\
\text { cryoprecipitate is recommended in order to reduce coagulopathy and } \\
\text { thrombocytopenia }\end{array}$ & $\begin{array}{l}\text { Cryoprecipitate } \\
5-10 \mathrm{~mL} / \mathrm{kg} \text { with higher } \\
\text { volumes in bleeding patients }\end{array}$ \\
\hline & & $\frac{\text { Guidance }}{\text { Massive blood loss aim fibrinogen }>150 \text { mg/dL }}$ & $\begin{array}{l}\text { Massive blood loss } \\
\text { Cryoprecipitate } \\
10 \mathrm{~mL} / \mathrm{kg}\end{array}$ \\
\hline
\end{tabular}

NBA (2) Neonatal and pediatric

specific PBM guideline

Practice Point

- In children, the decision to transfuse cryoprecipitate or fibrinogen concentrate should take into account the potential risks and benefits. The decision should be based not only on laboratory investigations but also on assessment of the patient's clinical condition. Factors that may influence the decision include active bleeding, medications affecting coagulation status, and congenital and acquired bleeding disorders

Expert opinion point

- Cryoprecipitate should be used to treat active bleeding when the fibrinogen level is $<150 \mathrm{mg} / \mathrm{dL}$.

- A target level of $200 \mathrm{mg} / \mathrm{dL}$ may be appropriate in certain situations (e.g., critical bleeding is occurring or anticipated)

\begin{tabular}{|c|c|c|}
\hline \multirow[t]{2}{*}{$\begin{array}{l}\text { Italian neonatal } \\
\text { transfusion } \\
\text { guideline, } 2015 \text { (3) }\end{array}$} & \multirow[t]{2}{*}{$\begin{array}{l}\text { Neonatal transfusion } \\
\text { guideline }\end{array}$} & $\begin{array}{l}\text { Recommended interventions } \\
\text { - Term and preterm neonates with hypofibrinogenemia but no bleeding, } \\
\text { observation is recommended }\end{array}$ \\
\hline & & $\begin{array}{l}\text { Recommended interventions } \\
\text { - Term and preterm neonates with hypofibrinogenemia and bleeding or } \\
\text { about to undergo an invasive procedure, cryoprecipitate is recommended }\end{array}$ \\
\hline SABM (4) & $\begin{array}{l}\text { Pediatric PBM } \\
\text { Standard in PBM } \\
\text { Guideline }\end{array}$ & $\begin{array}{l}\text { Indicators } \\
\text { - The decision to transfuse cryoprecipitate should be based on laboratory } \\
\text { studies, including point-of-care viscoelastic testing if available, fibrinogen } \\
\text { concentration, the patient's clinical status and the etiology of the patient's } \\
\text { coagulopathy } \\
\text { - Fibrinogen concentrate may alternatively be considered }\end{array}$ \\
\hline Faraoni, NATA (5) & $\begin{array}{l}\text { Pediatric cardiac } \\
\text { surgery guideline }\end{array}$ & $\begin{array}{l}\text { Recommendations } \\
\text { - The authors suggest FFP should be considered for treating } \\
\text { hypofibrinogenemia in bleeding neonates and children only when } \\
\text { cryoprecipitate or fibrinogen concentrates are not available } \\
\text { - In bleeding neonates and children, the authors recommend } \\
\text { hypofibrinogenemia diagnosed either by Clauss method ( }<150 \mathrm{mg} / \mathrm{dL} \text { ) or } \\
\text { viscoelastic tests (based on institution-specific algorithm) should be } \\
\text { treated either with cryoprecipitate or fibrinogen concentrate }\end{array}$ \\
\hline
\end{tabular}

Cryoprecipitate $5 \mathrm{~mL} / \mathrm{kg}$

Cryoprecipitate 5-10 mL/kg

\section{Cryoprecipitate}

Volume should be calculated based on weight and desired increase in fibrinogen concentration and improvement in coagulations indices 
TABLE 1 | Continued

\begin{tabular}{|c|c|c|c|}
\hline Guideline & $\begin{array}{l}\text { Type of guideline and } \\
\text { patient population }\end{array}$ & Transfusion guidance and indications & Dosing information \\
\hline $\begin{array}{l}\text { NICE guidelines } \\
2015 \text { (6) }\end{array}$ & $\begin{array}{l}\text { Guideline for adults, } \\
\text { young people, and } \\
\text { children over } 1 \text { year }\end{array}$ & $\begin{array}{l}\text { Generic Recommendations } \\
\text { - Do not offer cryoprecipitate transfusions to correct the fibrinogen level in } \\
\text { patients who: are not bleeding and are not having invasive procedures or } \\
\text { surgery with a risk of clinically significant bleeding } \\
\text { - Consider cryoprecipitate transfusions for patients with major hemorrhage } \\
\text { who have clinically significant bleeding and a fibrinogen level }<150 \mathrm{mg} / \mathrm{dL} \\
\text { - Consider prophylactic cryoprecipitate transfusions for patients with a } \\
\text { fibrinogen level }<100 \mathrm{mg} / \mathrm{dL} \text { who are having invasive procedures or } \\
\text { surgery with a risk of clinically significant bleeding }\end{array}$ & $\begin{array}{l}\text { Cryoprecipitate } \\
5-10 \mathrm{~mL} / \mathrm{kg} \text { up to a } \\
\text { maximum of } 2 \text { pools }\end{array}$ \\
\hline $\begin{array}{l}\text { Blood Easy 4, } \\
\text { Canada, } 2016 \text { (10) }\end{array}$ & $\begin{array}{l}\text { Blood } \\
\text { Transfusion Guideline }\end{array}$ & $\begin{array}{l}\text { Generic Indications } \\
\text { - For bleeding with fibrinogen }<100 \mathrm{mg} / \mathrm{dL} \\
\text { - For massive hemorrhage with fibrinogen }<150-200 \mathrm{mg} / \mathrm{dL} \\
\text { - For acute phase of APML with fibrinogen }<150 \mathrm{mg} / \mathrm{dL} \\
\text { - } \text { ICH secondary to treatment with } \mathrm{tPA} \text { with fibrinogen }<200 \mathrm{mg} / \mathrm{dL} \\
\text { - Treatment of bleeding in patients with } \mathrm{VWD} \text { or Hemophilia A, only when: } \\
\text { Factor concentrates are unavailable, remote geographic region and } \\
\text { DDAVP is unavailable or ineffective }\end{array}$ & $\begin{array}{l}\text { Cryoprecipitate } \\
\text { - } 1 \text { unit/10 kg body weight } \\
\text { to a maximum of } 10 \text { units } \\
\text { - }(\sim 4000 \text { mg fibrinogen })\end{array}$ \\
\hline
\end{tabular}

\section{Fibrinogen concentrate}

German Medical

Association, 2014

(7)
Blood Transfusion

Guideline with children. guidance for adults and

Recommendations-Acquired fibrinogen deficiency

- Fibrinogen can be substituted perioperatively in interventions or lesions with the risk of acute bleeding and confirmed fibrinogen deficiency (massive transfusion, dilution and loss coagulopathy)

- Fibrinogen can be substituted in synthesis disorders (liver damage) with fibrinogen deficiency or in hemorrhagic dysfibrinogenemias as prophylaxis and therapy of hemorrhage and confirmed fibrinogen deficiency

- Fibrinogen can be substituted as a prophylaxis and therapy of hemorrhage and confirmed fibrinogen deficiency of different origin (e.g., acute leukemia, asparaginase therapy, obstetrical complications, postoperatively)

General Recommendations - Acquired fibrinogen deficiency

- The critical threshold values for the occurrence of spontaneous bleeding are $<100 \mathrm{mg} / \mathrm{dL}$ (in severe hemorrhage $150 \mathrm{mg} / \mathrm{dL}$ )

- The fibrinogen level should always be specifically determined. An indirect determination using PT or APTT is not sufficient for any decisions regarding substitution therapy. The detection limit of the laboratory assay must be taken into account

- Following administration, fibrinogen levels should be monitored and maintained above the critical threshold value $(\sim 100 \mathrm{mg} / \mathrm{dL})$

\section{European trauma Adult trauma guideline ${ }^{\star}$} guideline, 2019 (8)
Generic Recommendations

Initial coagulation resuscitation

- In the initial management of patients with expected massive hemorrhage, we recommend one of the two following strategies:

- FFP or pathogen-inactivated FFP in a FFP:RBC ratio of at least 1:2 as needed.

- Fibrinogen concentrate and red cells Fibrinogen supplementation We recommend treatment with fibrinogen concentrate or cryoprecipitate if major bleeding is accompanied by hypofibrinogenemia (viscoelastic signs of a functional fibrinogen deficit or a plasma Clauss fibrinogen level $\leq 150 \mathrm{mg} / \mathrm{dL}$ ) Coagulation factor concentrate-based management

- If a CFC-based strategy is used, we recommend treatment with factor concentrates based on standard laboratory coagulation parameters and/or viscoelastic evidence of a functional coagulation factor deficiency

- We suggest that monitoring of FXIII be included in coagulation support algorithms and that FXIII be supplemented in bleeding patients with a functional FXIII deficiency
Fibrinogen concentrate Mean adult dose in acquired fibrinogen deficiency $3,000-5,000 \mathrm{~g}$

Fibrinogen concentrate Adult dose 3,000-4,000 g 
TABLE 1 | Continued

\begin{tabular}{lll}
\hline Guideline & $\begin{array}{l}\text { Type of guideline and } \\
\text { patient population }\end{array}$ & Transfusion guidance and indications \\
\hline ESA 2017 (9) & $\begin{array}{l}\text { Perioperative guideline } \\
\text { with pediatric surgery } \\
\text { section }\end{array}$ & $\begin{array}{l}\text { No specific recommendation made for fibrinogen replacement in pediatric } \\
\text { surgery, as neither the optimal threshold for initiation of fibrinogen } \\
\text { replacement nor the dose required to reach the targeted fibrinogen } \\
\text { concentration, have been proven by high-quality data }\end{array}$
\end{tabular}

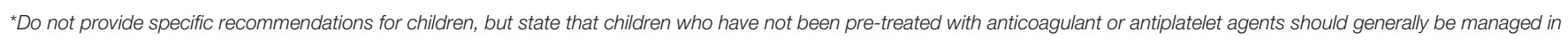
the same manner as the normal adult patient.

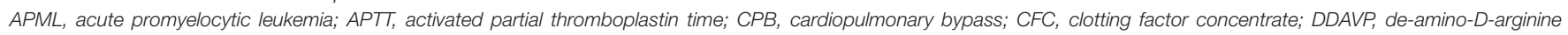

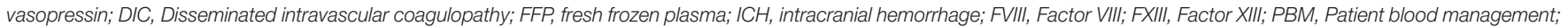
PCC, Prothrombin complex concentrate; RBC, red blood cells; PT, Prothrombin Time; tPA, tissue plasminogen activator; vWD, von Willebrand disease; vWF, von Willebrand factor.

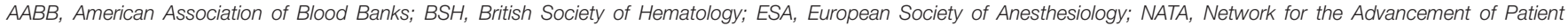

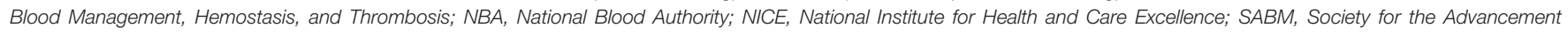
of Blood Management.

and hemostatic testing $(24,36)$. Most guidelines recommend against the transfusion of cryoprecipitate to correct coagulation abnormalities in neonates and children who are not bleeding $(24,25,38)$. However, guidance differs between transfusion guidelines with regard to product choice, clinical indications, target fibrinogen levels and doses, reflecting uncertainty, and lack of evidence in these areas. See Table $\mathbf{1}$ for further details.

\section{Variability in Practice}

It is not surprising, that given the paucity of evidence to support the use of cryoprecipitate and fibrinogen concentration that there is considerable variability in practice and inappropriate use $(45,46)$.

A single-center retrospective review of 44 critically ill children in the US found that cryoprecipitate was most commonly given in the setting of recent cardiac surgery, DIC, and sepsis (45). More than $60 \%$ of transfusions did not meet local institutional indications (45). Many children received cryoprecipitate empirically without a pre-transfusion fibrinogen level and the median dose received was higher than local guidelines suggested (45).

An Australian audit of cryoprecipitate use included 21 cryoprecipitate transfusion episodes for neonates (aged $<4$ months) and 24 for children (4 months-17 years). A pretransfusion fibrinogen level and an appropriate indication for transfusion were only present in $57 \%$ of neonates and $67 \%$ of children (47).

In summary, there are an increasing number of insufficiently powered RCTs that have evaluated fibrinogen supplementation. RCTs are mainly performed in adults, with only eight small published pediatric RCTs. Due to heterogeneity in clinical settings and indications, their results could not be pooled. There is some evidence in systematic reviews that prophylactic fibrinogen concentrate may result in reduced blood loss and reduced transfusion requirements, compared with inactive comparator. There is no evidence to favor cryoprecipitate or fibrinogen concentrate over one another.

Current guidance provided in international and national guidelines for fibrinogen replacement indications, thresholds and dosing are going to be limited by the lack of high quality and well-powered trials. Consensus recommendations or expert opinion statements are likely to be based on the results of a few underpowered trials in specific pediatric patient cohorts.

\section{INDICATIONS FOR FIBRINOGEN REPLACEMENT IN THE CRITICAL CARE SETTING}

\section{Reduced/Absent or Abnormal Fibrinogen Synthesis \\ Congenital Fibrinogen Disorders}

Acute presentations of congenital bleeding disorders are uncommon. Congenital fibrinogen disorders (afibrinogenemia and hypofibrinogenemia) are exceedingly rare, estimated incidence of 1-2 per million people (48). They are classified based on antigenic and functional levels of fibrinogen and include quantitative and qualitative defects (49). Afibrinogenemia is characterized by an undetectable fibrinogen level and results in a significant bleeding phenotype, with both spontaneous bleeding (e.g., umbilical cord, muscle, gingival, and intracranial hemorrhage $[\mathrm{ICH}])$, as well as trauma and surgery-associated bleeding $(50,51)$. ICH is a major cause of death in these patients $(51,52)$. Bleeding is typically less severe in hypofibrinogenemia and usually, but not always, correlates with the fibrinogen level (49).

Treatment of congenital fibrinogen disorders will depend on the bleeding phenotype, fibrinogen level and family history. Fibrinogen concentrate is the recommended fibrinogen replacement therapy to treat and prevent bleeding in patients with congenital fibrinogen disorders (53). A fibrinogen level of $100 \mathrm{mg} / \mathrm{dL}$ is typically targeted for treatment of minor bleeding, with a higher level of $150 \mathrm{mg} / \mathrm{dL}$ targeted for major bleeding, such as ICH (54).

Cryoprecipitate (preferably pathogen-reduced, where available) should only be used as an emergency treatment when fibrinogen concentrate is not accessible. In this context only, a dose of $15-20 \mathrm{~mL} / \mathrm{kg}$ of pathogen-reduced cryoprecipitate is suggested (55).

In summary, congenital fibrinogen disorders are rare. The optimal treatment and prevention of bleeding is fibrinogen concentrate. 
TABLE 2 | Randomized controlled trials of fibrinogen replacement in pediatrics.

\begin{tabular}{|c|c|c|c|c|c|c|}
\hline References & Setting & Population & Intervention & Comparator & $\begin{array}{l}\text { Fibrinogen } \\
\text { replacement }\end{array}$ & Outcomes \\
\hline \multicolumn{7}{|c|}{ Cardiac surgery } \\
\hline $\begin{array}{l}\text { Galas et al. } \\
\text { (17) }\end{array}$ & $\begin{array}{l}\text { Single } \\
\text { center-Brazil } \\
\text { Outcome } \\
\text { assessors } \\
\text { blinded }\end{array}$ & $\begin{array}{l}\text { Children }(<7 \\
\text { years) undergoing } \\
\text { cardiac surgery } \\
\text { and diffuse } \\
\text { bleeding after CPB } \\
\text { and fibrinogen } \\
\text { level }<100 \mathrm{mg} / \mathrm{dL} \\
N=63\end{array}$ & $\begin{array}{l}\text { Fibrinogen } \\
\text { concentrate (60 } \\
\mathrm{mg} / \mathrm{kg} \text { ) }\end{array}$ & $\begin{array}{l}\text { Cryoprecipitate } \\
(10 \mathrm{ml} / \mathrm{kg})\end{array}$ & $\begin{array}{l}\text { Haemocomplettan } \\
\text { P ® CSL Behring, } \\
\text { Germany }\end{array}$ & $\begin{array}{l}\text { FC }(n=30) \text { vs. Cryoprecipitate }(n=63) \\
{ }^{*} \text { Median } \mathbf{4 8} \text { h. blood loss }(\mathbf{m l}): \mathbf{3 2 0} \\
\text { (157-750) vs. } \mathbf{4 1 0}(\mathbf{2 1 5 - 5 1 0 ) ,} \boldsymbol{p}=\mathbf{0 . 6 7 2} \\
\text { Post-operative red cell transfusion: } 25 / 30 \\
\text { vs. } 32 / 33, p=0.094 \\
\text { Post-operative FFP: } 3 / 30 \text { vs. } 8 / 33, p= \\
0.137 \\
\text { Post-operative PIt: } 0 / 30 \text { vs. } 3 / 33, p= \\
0.24 \\
\text { Post-operative Cryo: } 13 / 30 \text { vs. } 14 / 33, p= \\
0.942 \\
\text { ICU stay (d.): } 10 \text { (6-25) vs. } 10 \text { (5-24), } p= \\
0.930 \\
\text { Hospital stay (d.): } 21 \text { (12-32) vs. } 20 \\
\text { (10-38), } p=0.895 \\
\text { Death: } 0 \text { vs. } 0\end{array}$ \\
\hline $\begin{array}{l}\text { Downey et } \\
\text { al. (18) }\end{array}$ & $\begin{array}{l}\text { Two centers } \\
\text { USA } \\
\text { Not blinded }\end{array}$ & $\begin{array}{l}\text { Infants }(<12 \\
\text { months) } \\
\text { undergoing } \\
\text { cardiac surgery } \\
\text { post CPB protocol } \\
N=59\end{array}$ & $\begin{array}{l}\text { Fibrinogen } \\
\text { concentrate (dose } \\
\text { to target } 300 \\
\mathrm{mg} / \mathrm{dL} \text { ) }\end{array}$ & $\begin{array}{l}\text { Cryoprecipitate (2 } \\
\text { units) }\end{array}$ & $\begin{array}{l}\text { RiaSTAP }{ }^{\circledR}, C S L \\
\text { Behring, Germany }\end{array}$ & $\begin{array}{l}\frac{F C(n=30) \text { vs. Cryoprecipitate }(n=29)}{} \\
\frac{-I T \text { analysis }}{{ }^{*} \text { Total all blood product }(\mathbf{U}): \mathbf{4}(\mathbf{3}-\mathbf{5}) \text { vs. }} \\
\mathbf{5 . 5}(\mathbf{4 - 7}), \boldsymbol{p}=\mathbf{0 . 0 0 7} \\
\text { Total red cells }(\mathrm{U}): 2(1-2.8) \text { vs. } 2(1-2), p \\
=0.383 \\
\text { Total FFP (U): } 1(1-1) \text { vs. } 1(0-1), p= \\
0.263 \\
\text { Total PIt (U): } 1(1-1) \text { vs. } 1(1-1), p=0.257 \\
\text { Total Cryo (U): } 0(0-0) \text { vs. } 2(2-2), p<0.001\end{array}$ \\
\hline
\end{tabular}


TABLE 2 | Continued

\begin{tabular}{|c|c|c|c|c|c|}
\hline References & Setting & Population & Intervention & Comparator & $\begin{array}{l}\text { Fibrinogen } \\
\text { replacement }\end{array}$ \\
\hline $\begin{array}{l}\text { Siemens et } \\
\text { al. (32) }\end{array}$ & $\begin{array}{l}\text { Single- } \\
\text { centre UK } \\
\text { Partially } \\
\text { blinded } \\
\text { Trial team not } \\
\text { blinded, } \\
\text { treating } \\
\text { clinicians and } \\
\text { patients blinded }\end{array}$ & $\begin{array}{l}\text { Infants }(2.5-12 \mathrm{~kg}) \\
\text { undergoing } \\
\text { cardiopulmonary } \\
\text { bypass surgery } \\
N=111 \text { (monitor } \\
\text { cohort, } n=21 \text {; } \\
\text { FC, } n=60 \\
\text { placebo, } n=30 \text { ) }\end{array}$ & $\begin{array}{l}\text { Fibrinogen } \\
\text { concentrate } \\
\text { (individualized } \\
\text { dose targeted to } \\
\text { FIBTEM-MCF of } \\
8-13 \mathrm{~mm} \text { ) }\end{array}$ & $\begin{array}{l}\text { Placebo (0.9\% } \\
\text { sodium chloride) }\end{array}$ & $\begin{array}{l}\text { RiaSTAP }{ }^{\circledR}, C S L \\
\text { Behring, Germany }\end{array}$ \\
\hline
\end{tabular}

Outcomes

FC $(n=29)$ vs. Cryoprecipitate $(n=25)$

-PP analysis

Chest tube output (mL/kg): 16.1 (12.6-25)

vs. 18.1 (10.9-26), $p=0.671$

ICU stay (d.): 3 (2-7) vs. 4.5 (2-6), $p=$

0.487

Hospital stay (d.): 7 (4-11) vs. 8 (5-19), $p$

$=0.342$

Death within 30 day: 1 vs. 0

FC $(n=60)$ vs. Placebo $(n=30)$

*FibTEM-MCF post dose (mm): 13.0

(3.2) vs. 4.5 (1.7)

*Fibrinogen level post dose (g/L): 1.7

(0.4) vs. $0.7(0.2)$

$24 \mathrm{~h}$ mediastinal drain loss (ml/kg): 11.6

(5.2) vs. 17.1 (14.3), $p=0.02$

Perioperative red cells, $n$ (\%): 21 (35\%) vs. $12(40 \%)$

Perioperative FFP $n$ (\%): 3 (5\%) vs. 5

(16.7\%)

Perioperative PIt $n(\%): 8$ (13.3\%) vs. 5

(16.7\%)

Perioperative Cryo $n$ (\%): 5 (8.3\%) vs. 2

(6.7\%)

Thrombosis: 10 vs. 2

\section{Craniosynostosis surgery}

\section{Haas et al. Single}

(29) center-

Switzerland

Staff in

PICU blinded
Children (median

age 10 months)

undergoing

craniosynostosis

surgery $N=30$
Early Fibrinogen

replacement

FIBTEM MCF

$<13 \mathrm{~mm}$
Conventional

Fibrinogen

replacement

FIBTEM

$\mathrm{MCF}<8 \mathrm{~mm}$
Haemocomplettan

$P^{\circledR}$ CSL Behring,

Germany (30

$\mathrm{mg} / \mathrm{kg})^{\#}$

Early $(n=13)$ vs. conventional $(n=17)$ fibrinogen replacement

${ }^{*}$ Total red cells in $24 \mathrm{~h}$. (ml/kg): 28.2

(21.2-49.9) vs. $55.5(27.5-61.8), p=0.03$

Total FFP in $24 \mathrm{~h}$. (mL/kg): 0 vs. $0, p=$ 0.97

Total Plt in $24 \mathrm{~h}$. (mL/kg): 0 vs. $0, p=0.43$ Calculated blood loss (\%): 90 (78-113) vs. 157 (111-187), $p=0.02$

ICU stay (d.): $1(1-1)$ vs. $1(1-1), p=0.59$

Hospital stay (d.): 9 (9-9) vs. 9 (9-9), p

$=0.54$

\begin{tabular}{|c|c|c|c|c|c|c|}
\hline $\begin{array}{l}\text { Machotta et } \\
\text { al. (31) }\end{array}$ & $\begin{array}{l}\text { Single center } \\
\text { Netherlands } \\
\text { Blinded }\end{array}$ & $\begin{array}{l}\text { Infants and } \\
\text { children (5-25 } \\
\text { months) } \\
\text { undergoing } \\
\text { craniosynostosis } \\
\text { surgery } \\
N=114 \text { (111 in } \\
\text { final analysis) }\end{array}$ & $\begin{array}{l}\text { Fibrinogen } \\
\text { concentrate (dose } \\
\text { to target } 300 \\
\mathrm{mg} / \mathrm{dL} \text { ) }+ \text { infusion } \\
60 \mathrm{mg} / \mathrm{kg}\end{array}$ & Placebo & $\begin{array}{l}\text { Haemocomplettan } \\
\mathrm{P}^{\circledR} \text { CSL Behring, } \\
\text { Germany }\end{array}$ & 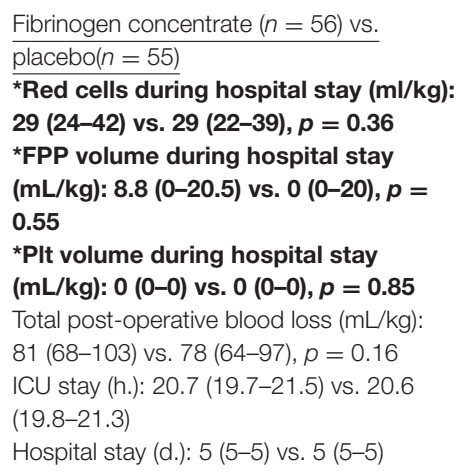 \\
\hline \multicolumn{7}{|c|}{ Scoliosis surgery } \\
\hline $\begin{array}{l}\text { Haas et al. } \\
\text { (29) }\end{array}$ & $\begin{array}{l}\text { Single } \\
\text { center- } \\
\text { Switzerland } \\
\text { Staff in } \\
\text { PICU blinded }\end{array}$ & $\begin{array}{l}\text { Children (median } \\
\text { age } 12 \text { years) } \\
\text { undergoing } \\
\text { scoliosis surgery } N \\
=19\end{array}$ & $\begin{array}{l}\text { Early Fibrinogen } \\
\text { replacement } \\
\text { FIBTEM MCF } \\
<13 \mathrm{~mm}\end{array}$ & $\begin{array}{l}\text { Conventional } \\
\text { replacement } \\
\text { FIBTEM } \\
\text { MCF }<8 \mathrm{~mm}\end{array}$ & $\begin{array}{l}\text { Haemocomplettan } \\
\mathrm{P}^{\circledR} \text { CSL Behring, } \\
\text { Germany ( } 30 \\
\mathrm{mg} / \mathrm{kg})^{\#}\end{array}$ & 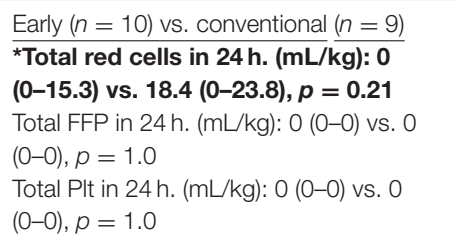 \\
\hline
\end{tabular}


TABLE 2 | Continued

\begin{tabular}{|c|c|c|c|c|c|c|}
\hline References & Setting & Population & Intervention & Comparator & $\begin{array}{l}\text { Fibrinogen } \\
\text { replacement }\end{array}$ & Outcomes \\
\hline & & & & & & $\begin{array}{l}\text { Calculated blood loss (\%): } 36.5 \\
\text { (14.9-54.3) vs. } 51 \text { (38.5-69.2), } p=0.17 \\
\text { ICU stay (d): } 1(1-1) \text { vs. } 1(1-1), p=0.5 \\
\text { Hospital stay (d.): } 8 \text { (8-10) vs. } 8(6-13), p \\
=0.57\end{array}$ \\
\hline
\end{tabular}

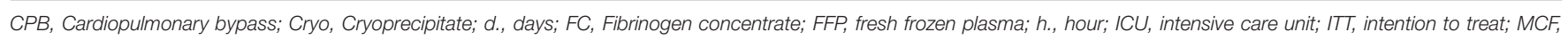
maximum clot firmness; PP, per protocol; Plt, platelets; U, units; UK, United Kingdom; US, United States of America.

* (in bold) Primary outcome of study.

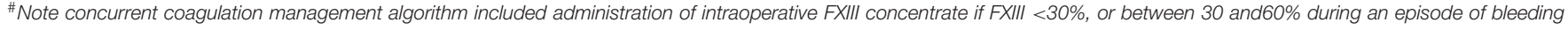
requiring transfusion.

\section{Liver Disease}

The liver plays a key role in the synthesis of multiple hemostatic proteins. Acquired hypofibrinogenemia may be seen when hepatic damage is severe enough to compromise synthetic liver function (56). Liver dysfunction also results in dysfibrinogenemia, with synthesis of an abnormally functioning fibrinogen (56).

In children with severe liver-disease, our understanding of hemostasis is predominantly derived from the adult literature (10). However, this may not be appropriate, given the etiologies of pediatric liver failure differ considerably compared with those seen in adults (57) and hemostasis is age-dependent.

In adults with cirrhosis, low fibrinogen levels $(<60 \mathrm{mg} / \mathrm{dL})$ have been highlighted as a predictor for major bleeding (58). Prophylactic fibrinogen replacement has been evaluated in on a RCT conducted in adults undergoing liver transplantation randomized to prophylactic fibrinogen concentrate (dosed to target Fibrinogen of $290 \mathrm{mg} / \mathrm{dL}$ ) vs. placebo (59). The study found no difference in the study's primary outcome of red cell transfusion requirements (59).

Low quality recommendations or consensus statements are made regarding fibrinogen supplementation in adult liver disease guidelines. Most advise against prophylactic replacement of coagulation factors and that replacement be limited to instances of active bleeding or high-risk invasive procedures (60-63). Some guidelines specify that in the context of active bleeding, a fibrinogen level of $>100 \mathrm{mg} / \mathrm{dL}$ be maintained $(61,64)$.

However, this has not been established in pediatric studies. Children with liver failure rarely develop significant spontaneous bleeding (65) indicating that our understanding of the hemostatic equipoise seen in infants and children with advanced liver disease is limited (10). The role of prophylactically correcting laboratory values in children who are not bleeding or undergoing invasive procedures needs to be justified. However, in the context of active bleeding, children with acquired hypofibrinogenemia secondary to liver disease may benefit from fibrinogen replacement (65).

In summary, the risk of bleeding in children with advanced liver disease and acquired hypofibrinogenemia appears to be less than in adults. Therefore, routine prophylactic fibrinogen supplementation is not advised. There may, however, be a role for correcting hypofibrinogenemia in the context of significant bleeding and advanced liver disease.

\section{L-Asparaginase}

L-asparaginase is a key component in pediatric acute lymphoblastic leukemia (ALL) induction chemotherapy protocols $(66,67)$. As a secondary effect it inhibits the synthesis of hepatic L-asparagine dependent proteins, leading to significant reductions in antithrombin and fibrinogen (68). Hypofibrinogenemia is frequently seen (67), however due to reduced antithrombin levels, thrombotic rather than bleeding complications are encountered (66).

There is a paucity of evidence evaluating fibrinogen replacement in children with acute leukemia and thresholds are largely consensus based and derived from other clinical settings (69). Prophylactic fibrinogen supplementation in this setting is controversial (69-71). Some advocate for therapeutic-only treatment or when there is an increased risk of bleeding due to comorbidity (70). Others recommend prophylactic cryoprecipitate in all oncology patients with acquired hypofibrinogenemia secondary to medications $(72,73)$.

In summary, L-asparaginase is frequently used to treat pediatric $A L L$ and commonly causes acquired hypofibrinogenemia. Current evidence does not point towards an increased bleeding tendency. 
Therefore, many pediatric ALL protocols do not recommend prophylactic correction with fibrinogen replacement. The role of fibrinogen supplementation in the bleeding child receiving $L$ asparaginase is unknown.

\section{Fibrinogen Loss Exceeding Fibrinogen Production}

Massive blood loss may be encountered in children, in the setting of refractory surgical bleeding and trauma (74). Fibrinogen is the first coagulation factor to fall to a critical level of 100 $\mathrm{mg} / \mathrm{dL}$ and may be encountered after loss or replacement of 1-1.5 blood volumes (75). Additional factors that may contribute to hypofibrinogenemia developing in pediatric trauma and surgical settings include: lower baseline fibrinogen levels in children, hemodilution from crystalloids, or unbalanced hemostatic resuscitation (11), clotting factor consumption, as well as hyperfibrinolysis.

\section{Pediatric Cardiac Surgery}

Neonates and children undergoing major cardiac surgery are at risk of post-operative bleeding and as a result, commonly receive red cell transfusions (76). Cardiopulmonary bypass (CPB) results in hemodilution, clotting factor consumption, platelet dysfunction, and fibrinolysis (77).

We identified five completed RCTs $(n=295)$ specific to the pediatric cardiac surgical setting $(17,18,32-34)$. See Table 2 for further details of these studies.

Two RCTs have compared fibrinogen concentrate with placebo, one as part of a TEG-guided transfusion strategy (33) and the other, as part of a feasibility study evaluating intraoperative ROTEM for screening patients at risk of bleeding (32). A further RCT was identified, comparing fibrinogen concentrate with FFP (34).

Cui et al. randomized 40 children (of which 31 were analyzed) with cyanotic heart disease undergoing cardiac surgery to a TEG-guided transfusion strategy using fibrinogen concentrate (500-1,000 mg) compared to a transfusion guided by clinical experience strategy (without fibrinogen concentrate), with a primary outcome of time to chest wall closure (33). There was no significant difference seen in time to chest wall closure, nor total red cell or platelet usage between study arms. There was, however, statistically lower FFP usage in the fibrinogen concentrate arm, $(p$ $=0.006$ ). Unfortunately, the study was not blinded, intention-totreat principle was not applied, and no information was provided about the median dose, the number or timing of fibrinogen concentrate doses, or the TEG intervention points or any adverse events, limiting its applicability to other settings (33). Use of anti-fibrinolytics was not reported.

Siemens et al. enrolled 111 infants with congenital heart disease undergoing $\mathrm{CPB}$ surgery to investigate the feasibility of using intraoperative ROTEM $^{\circledR}$ as a screening tool to predict post-operative bleeding and guide fibrinogen replacement (32). The trial included a monitoring arm of 21 children with a FIBTEM-Maximum Clot Firmness (MCF) $>7 \mathrm{~mm}$ and an intervention arm (FIBTEM-MCF $<6 \mathrm{~mm}$ ) comprising 60 children randomized to individually-dosed fibrinogen concentrate (target FIBTEM-MCF $8-13 \mathrm{~mm}$ ) and 30 to placebo
(32). Co-primary outcomes were FIBTEM-MCF and fibrinogen levels 5 min post fibrinogen concentrate/placebo administration (32). In addition, the study aimed to review the dosing, safety, and efficacy of fibrinogen concentrate. Whilst FIBTEM-MCF and fibrinogen levels were higher in the fibrinogen concentrate arm, no $p$-values were provided. The study was not powered for efficacy outcomes and the authors did not report $p$-values for any transfusion data. They did however, report significantly lower 24-h mediastinal drain losses in those receiving fibrinogen concentrate $(p=0.02)$. Ten cases of thromboembolism were reported in children who received fibrinogen concentrate compared with two in the placebo arm (32). The study was partially blinded; clinicians and patients were blinded to treatment group. All patients received tranexamic acid.

One RCT was identified where fibrinogen concentrate was compared with FFP (34). Massoumi et al. randomly allocated children undergoing cardiac surgery to receive either FFP (10 $\mathrm{ml} / \mathrm{kg}$ ) or fibrinogen concentrate $(70 \mathrm{mg} / \mathrm{kg})$, with a primary outcome of post-operative chest tube drainage. The study reported that chest tube drainage was less in those receiving fibrinogen concentrate $(p=0.04)$. Although not statistically significant due to low numbers, more blood products were given in the FFP-arm. Limitations of the study include the lack of blinding and the method of randomization. Only the first patient was randomized to the fibrinogen treatment arm and subsequent children allocated to FFP or fibrinogen in a 1:1 ratio. Antifibrinolytics were not routinely administered.

Two additional RCTs have been conducted comparing cryoprecipitate with fibrinogen concentrate: one in the setting of post-operative bleeding (17) and one as part of a post-CPB protocol (18).

Galas et al. randomized 63 children with diffuse bleeding after $\mathrm{CPB}$ and fibrinogen $<100 \mathrm{mg} / \mathrm{dL}$ to receive $10 \mathrm{~mL} / \mathrm{kg}$ of cryoprecipitate vs. $60 \mathrm{mg} / \mathrm{kg}$ fibrinogen concentrate with a primary outcome of 48 -h postoperative blood loss (17). The study found no difference in 48 -h blood loss; $320 \mathrm{~mL}$ in the fibrinogen concentrate arm vs. $410 \mathrm{~mL}$ in those who received cryoprecipitate $(p=0.672)$. There was no statistical difference seen in red cell transfusion rates between study arms; $83.3 \%$ of the fibrinogen concentrate arm received a red cell transfusion compared with $97 \%$ in the cryoprecipitate arm $(p=0.094)(17)$. Both fibrinogen concentrate, and cryoprecipitate improved fibrinogen levels post intervention. However, there was no difference seen in fibrinogen levels or FIBTEM-MCF between treatment arms and no difference seen for other secondary outcomes (17). Limitations of the study include the lack of blinding of study personnel to treatment allocation. Other considerations are that the cryoprecipitate arm included a higher proportion of neonates and a longer period of cardiopulmonary bypass. Also, more than $40 \%$ of patients in both the cryoprecipitate and fibrinogen study groups received additional doses of cryoprecipitate within the first seven post-operative days (17). All patients received $\varepsilon$-aminocaproic acid.

Downey et al. included 59 infants undergoing cardiac surgery randomized to receive two units of cryoprecipitate or fibrinogen concentrate (dosed to target Fibrinogen of $300 \mathrm{mg} / \mathrm{dL}$ ) as part of a post-CPB hemostasis algorithm with a primary outcome of 
intraoperative transfusions (18). There was no difference in the red cell, FFP or platelet components received between treatment groups, but the fibrinogen concentrate arm received 1.79 less total blood products compared with the cryoprecipitate arm (intention to treat analysis), likely reflecting the intervention of two units cryoprecipitate (18). Both fibrinogen concentrate, and cryoprecipitate improved fibrinogen levels post intervention. In the per protocol analysis, immediately after administration of fibrinogen supplementation, the median fibrinogen level in the fibrinogen concentrate arm was higher $(314.5 \mathrm{mg} / \mathrm{dL}$ [IQR: 296.5-342.5]) than the cryoprecipitate arm $(276.5 \mathrm{mg} / \mathrm{dL}$ [IQR: 192.2-323.5]) $(p=0.025)$. There was also a narrower interquartile range in the fibrinogen concentrate arm, reflecting less variability in the fibrinogen level achieved. A consideration must be the dosing strategy, since the fibrinogen concentrate arm had their dose calculated based on weight, whilst the cryoprecipitate group were administered a standardized dose. The dose of two units cryoprecipitate was based on the author's previous experience and was expected to achieve a post-infusion fibrinogen level of $345 \mathrm{mg}$. In the study, this dose did not result in the desired level, in is unclear if the reflects product fibrinogen variability or insufficient dosing for weight. There was no difference seen for any secondary outcomes or adverse events. Limitations of the study are that it was not blinded, it was conducted over two centers and there were differences between the two centers with respect to their cardio-pulmonary bypass protocols, the use of four factor prothrombin complex concentrate and the type of antifibrinolytics used. One center used tranexamic acid and the other $\varepsilon$-aminocaproic acid for neonates and those undergoing a re-do sternotomy (18).

An important RCT from the adult cardiac setting included 735 adults with post-operative bleeding and hypofibrinogenemia randomized to 10 units of cryoprecipitate or $4 \mathrm{~g}$ of fibrinogen concentrate, with a primary outcome of 24-h cumulative blood products after CPB (78). No difference was seen in the study's primary outcome and no difference was found for secondary transfusion outcomes, mortality or other relevant clinical outcomes (78). It is important to note that the fibrinogen concentrate used (Fibryga ${ }^{\circledR}$ ) has much higher levels of FXIII than other fibrinogen concentrates (79).

These studies do not infer superiority of either cryoprecipitate or fibrinogen concentrate but suggest that fibrinogen concentrate may be an alternate, safe, and effective fibrinogen replacement therapy to cryoprecipitate, in the pediatric cardiac surgical setting.

The importance of fibrinogen supplementation in children undergoing cardiac surgery, with evidence of hypofibrinogenemia has been recognized in clinical guidelines. The Network for the Advancement of Patient Blood Management, Haemostasis, and Thrombosis (NATA) pediatric cardiac surgery guidelines recommend that hypofibrinogenemia diagnosed by either Clauss method $(<150 \mathrm{mg} / \mathrm{dL})$ or viscoelastic tests (based on an institution-specific algorithm) should be treated with cryoprecipitate or fibrinogen concentrate (37). See Table 1.

\section{Pediatric Surgery}

Children undergoing cardiothoracic surgery, liver transplantation, craniofacial and neurosurgical procedures, hepatobiliary surgeries, and tumor resection procedures have a high frequency of transfusion (80) and may need PICU admission (81). Craniosynostosis surgery in particular, is frequently associated with coagulopathy and transfusion. Hypofibrinogenemia has been identified as a major risk factor for bleeding in this setting (82).

Our review identified three trials $(n=262)$ evaluating fibrinogen supplementation in the scoliosis and craniosynostosis surgery settings (29-31). See Table 2 for further details.

The timing of preemptive fibrinogen concentrate use has been studied in one pediatric RCT combining infants (median age 10 months) undergoing craniosynostosis surgery and adolescents (median age 12 years) undergoing scoliosis repair (29). Haas et al. randomized 30 children to receive $30 \mathrm{mg} / \mathrm{kg}$ fibrinogen concentrate at two predefined FIBTEM cut-offs, a MCF of $<8 \mathrm{~mm}$ (conventional arm) vs. $<13 \mathrm{~mm}$ (early substitution arm) with a primary outcome of cumulative volume of red cells received in the first $24 \mathrm{~h}$. Red cell transfusion requirements in the craniosynostosis group were significantly lower in the early fibrinogen replacement group ( 28 vs. $56 \mathrm{~mL} / \mathrm{kg}, p=$ $0.03)$. In addition, total blood loss was less in the early fibrinogen replacement group ( 89.7 vs. $156.9 \%, p=0.02$ ). There was however, no difference found for red cell transfusion requirements or blood loss in the scoliosis cohort. It is important to note that FXIII replacement was included as part of the study protocol and all subjects received tranexamic acid (29). Specific study limitations were that it was only partially blinded, with only PICU staff blinded to intervention arm and the small sample sizes of the two surgical cohorts. The study ceased early due to difficulties with recruitment with only 57 (instead of 60) subjects randomized. In addition, seven of the 26 randomized scoliosis patients did not meet the FIBTEM trigger for fibrinogen supplementation and could not be included in the analysis (29).

To evaluate the effect of prophylactic administration of fibrinogen concentrate in the craniosynostosis surgery setting, Machotta et al. randomized 114 children to receive fibrinogen concentrate vs. placebo, with a primary outcome of transfusion volume during hospital stay (31). Fibrinogen concentrate (dose to target a fibrinogen of $300 \mathrm{mg} / \mathrm{dL}$ [median dose 79 $\mathrm{mg} / \mathrm{kg}]$ ), followed by an infusion of $60 \mathrm{mg} / \mathrm{kg}$ during the first hour of surgery (31). Of the 111 children analyzed, fibrinogen concentrations were significantly higher in the fibrinogen treatment arm, but there was no significant difference between the study arms with regard to the transfusion volume, perioperative blood loss, or secondary outcomes. Median volume of red cells received by patients was $29 \mathrm{~mL} / \mathrm{kg}$ in both the fibrinogen concentrate and placebo arms $(p=0.36)$ (31). This was a double-blinded placebo-controlled trial and the authors attempted to limit confounders, by restricting use of perioperative tranexamic acid, heparin, or non-steroidal antiinflammatory drugs. They did, however, allow the use of hydroxyethyl starch (HES) which can cause falsely reduced fibrinogen levels (83). Limitations of the study were the slow 
study recruitment and early termination after 114 out of the planned 120 patients. Three patients were excluded from the final analysis because they received the wrong intervention or no intervention (83).

Chen et al. conducted a blinded RCT, comparing prophylactic fibrinogen concentrate $(30 \mathrm{mg} / \mathrm{kg})$ with placebo in 102 adolescents with idiopathic scoliosis undergoing surgery (30). The study's primary outcome was perioperative blood loss, which included intraoperative blood loss and postoperative wound drainage. Fibrinogen concentrate resulted in statistically reduced perioperative blood loss, median reduction of $155 \mathrm{~mL}$ (95\%CI: 5-320 mL) ( $p=0.04)$ compared with the placebo arm. There was no difference found in transfusion rates between study arms. Administration of fibrinogen concentrate resulted in statistically increased fibrinogen levels and MA on the TEG-FF assay. Postoperative fibrinogen levels were inversely correlated with postoperative bleeding $(p<0.001)$ (30). All patients received tranexamic acid and intraoperative cell salvage. The trial stopped prematurely due to a shortage in fibrinogen concentrate, with 102 out of the intended 104 participants recruited (30).

RCTs from both the pediatric cardiac and craniofacial surgery setting suggest that there are different risk factors that influence the need for fibrinogen supplementation. A prospective study looking at predictors of blood loss and red cell transfusion in children undergoing craniosynostosis surgery, found that the type of procedure, the duration of surgery, in addition to postoperative TEG parameters, $\alpha$-angle, MA, and K-time were all associated with transfusion. Based on these results they developed a TEG-based predictive algorithm for children with critical blood loss $(>60 \mathrm{~mL} / \mathrm{kg})$ to guide administration of hemostatic products, including fibrinogen concentrate (84).

The 2016 European guideline for the management of severe perioperative bleeding, do not make any recommendation for fibrinogen replacement in pediatric surgery, stating that neither the optimal threshold for initiation of fibrinogen replacement nor the dose required to reach the targeted fibrinogen concentration have been proven by high quality data (41).

In contrast, both the Australian pediatric PBM guidelines and National Institute for Health and Care Excellence (NICE) 2015 guidelines provide guidance around using cryoprecipitate to treat active bleeding in surgical settings when the fibrinogen is $<150$ $\mathrm{mg} / \mathrm{dL}(24,39)$. Neither of these guidelines however, mention FIBTEM or TEG-FF thresholds. See Table 1.

\footnotetext{
In summary, hypofibrinogenemia is recognized as a risk factor for perioperative bleeding, in both cardiac and general pediatric surgery. The highest quality evidence for the use of fibrinogen supplementation in children is found in the pediatric cardiac, scoliosis and craniofacial surgery settings. A number of small RCTs (mean number of participants 77, range [31-111]) have been performed. Results from systematic reviews published and RCTs appear to indicate that fibrinogen concentrate may reduce bleeding and reduce the risk of a patient needing a transfusion, compared with no intervention. Unfortunately, current data cannot be pooled due to heterogeneity. Therefore, we can only conclude, that there may be a role for fibrinogen supplementation in young children undergoing high-risk surgical procedures. No superiority of cryoprecipitate compared with fibrinogen concentrate have been
}

demonstrated. Thrombo-embolic events should be considered in children receiving fibrinogen replacement.

\section{Pediatric Trauma}

Accidental injuries are the leading cause of death in children and high rates of blunt trauma and traumatic brain injury (TBI) are seen in children compared with adult trauma patients (12, 85,86 ). Acute traumatic coagulopathy is commonly encountered in severely injured children prior to the administration of fluids and transfusion (87-90). Prolonged PTs/elevated INRs in trauma patients, including those with TBI appear associated with increased mortality $(12,87,91)$. Whilst hypofibrinogenemia has been reported to be an independent predictor of mortality in adult major trauma patients $(92,93)$, this has not been consistently shown in pediatric studies $(12,87,90,94)$.

In the adult trauma setting, validation studies in the ROTEM $^{\circledR}$ have shown that the FIBTEM CA5 (clot amplitude at $5 \mathrm{~min}$ ) (95), FIBTEM-MCF and FIBTEM A10 (clot amplitude at $10 \mathrm{~min}$ ) (96) may be used to predict patients requiring massive transfusion and be used as triggers for fibrinogen supplementation. In the pediatric trauma setting, viscoelastic testing is increasingly used, but studies are needed to establish intervention thresholds (97).

At this moment, there is no high-quality evidence that treatment of hypofibrinogenemia in pediatric trauma patient results in improved patient outcomes. A single case report discusses the successful use of fibrinogen concentrate in a pediatric trauma patient with severe abdominal and pelvic injuries after blunt trauma, without the need for FFP or platelet transfusion (98). However, in the adult combat setting, a retrospective review of 252 trauma patients in Iraq, found that delivery of a higher fibrinogen to red cell ratio was independently associated with improved survival in patients requiring massive transfusion (99).

Nevertheless, pediatric consensus transfusion guidelines do support fibrinogen replacement during critical bleeding and massive blood loss $(24,25)$. The British Society of Hematology (BSH) advises to target a fibrinogen of $>150 \mathrm{mg} / \mathrm{dL}$ in massive blood loss and after $>40 \mathrm{~mL} / \mathrm{kg}$ red cells to consider cryoprecipitate transfusion (25). The Australian guidelines support the use of higher targets of $200 \mathrm{mg} / \mathrm{dL}$ during critical bleeding, using cryoprecipitate (24). Recent European trauma guidelines do not provide specific recommendations for children, but state that children in general can be managed the same way as adults (100). They recommend one of two initial resuscitation strategies for massive hemorrhage; either FFP and red cells in a ratio of at least 1:2 or fibrinogen concentrate and red cells (100). If there is major bleeding and hypofibrinogenemia (viscoelastic signs of functional fibrinogen deficit or fibrinogen $<150 \mathrm{mg} / \mathrm{dL}$ ) they recommend fibrinogen supplementation with either fibrinogen concentrate or cryoprecipitate (100). However, if fibrinogen concentrate-based management is used, they suggest that FXIII be included in coagulation support algorithm (100). See Table 1.

The Fibrinogen Early in Severe Trauma Study (FEISTY) Junior is an Australian pediatric feasibility RCT comparing the use of early fibrinogen concentrate against cryoprecipitate 
in children with severe trauma using a ROTEM ${ }^{\circledR}$ based transfusion algorithm (FIBTEM A5 $<10 \mathrm{~mm}$ as their threshold for intervention) (101). The study's primary outcomes include: time to administration of fibrinogen replacement, feasibility outcomes, and effect on fibrinogen levels (101).

In summary, coagulopathy including hypofibrinogenemia frequently occurs in pediatric trauma patients. There is limited evidence in the literature supporting or refuting fibrinogen supplementation in the pediatric trauma settings. Both cryoprecipitate and fibrinogen concentrate are widely used to provide fibrinogen supplementation in pediatric trauma patients and form key components in pediatric massive transfusion protocols, with evidence extrapolated from adult trials. More research is needed to identify pediatric categories and triggers in which fibrinogen supplementation is beneficial.

\section{Hyperfibrinolysis}

\section{Disseminated Intravascular Coagulopathy}

Disseminated intravascular coagulopathy (DIC) is an acquired, life-threatening condition, resulting in systemic coagulation activation and is associated with both bleeding and thrombosis (102). In children, DIC most commonly occurs secondary to sepsis, but may be seen after major trauma, TBI, malignancy, snakebites, and in vascular malformations (14). The diagnosis of DIC is based on the presence of an underlying causative disorder in conjunction with a combination of laboratory features, including hypofibrinogenemia and fibrinolysis (103). Fibrinogen levels as a single parameter are insensitive in predicting DIC, as they may be elevated as an acute phase reactant and therefore serial testing may be important (104).

The most important aspect of DIC management is timely and appropriate treatment of the underlying condition (103). Transfusion should be reserved for children with active bleeding and should not be given based on laboratory parameters alone (14). The International Society of Thrombosis and Hemostasis (ISTH) recommend fibrinogen replacement only in patients with active bleeding and persistently low fibrinogen levels $<150$ $\mathrm{mg} / \mathrm{dL}$ despite treatment with FFP (103). The more recent $\mathrm{BSH}$ pediatric transfusion guideline recommends cryoprecipitate be given if the fibrinogen is $<100 \mathrm{mg} / \mathrm{dL}$ despite FFP or in conjunction with FFP for a very low or rapidly falling fibrinogen (25).

In summary, DIC is a clinico-pathological diagnosis. The focus of management of DIC should focus primarily on treating the underlying condition. The role of fibrinogen replacement is subject to debate but may be indicated in children with clinically significant bleeding and severe hypofibrinogenemia. The optimal fibrinogen replacement product is unknown.

\section{Extracorporeal Membrane Oxygenation}

Extracorporeal membrane oxygenation (ECMO) is increasingly used in neonatal and pediatric critical settings to provide lifesaving cardiopulmonary support (3). Neonates and children make up more than half of all ECMO runs reported to the international ELSO registry (105). ECMO circuits comprise artificial and non-endothelial surfaces that, when presented to patient blood, result in fibrinogen adsorption, contact pathway activation, coagulation activation, thrombin generation and fibrinolysis $(13,106)$. ECMO provokes a significant hemostatic challenge, and as a result both bleeding and thrombotic complications are commonly reported $(3,107,108)$. Bleeding in children on ECMO is significantly associated with an increased risk of death $(3,107,108)$.

A prospective observational cohort study of 514 pediatric and neonatal ECMO patients identified major bleeding (defined as blood loss requiring transfusion or ICH) in more than $70 \%$ of children (3). Whilst fibrinogen levels were monitored on more than $90 \%$ of ECMO days, a low fibrinogen was not identified as a risk factor for bleeding (3). In contrast, a small retrospective study of 32 neonates with persistent pulmonary hypertension requiring ECMO reported that low fibrinogen levels were associated with a higher incidence of ICH (109).

It is advised that fibrinogen levels are regular monitored $(108,110,111)$, however no RCTs have been performed in this patient cohort looking at fibrinogen thresholds and supplementation and hence there is no consensus on the desired fibrinogen levels needed (110). There is variable practice with respect to fibrinogen supplementation in this cohort. The ELSO guidelines, advise for transfusions of plasma or cryoprecipitate to maintain fibrinogen levels $>150 \mathrm{mgd} / \mathrm{L}$ in neonates (112) and 250-300 mg/dL in children $(111,112)$. Whilst other centers report targeting fibrinogen levels $>100-150$ $\mathrm{mg} / \mathrm{dL}$ in neonates (108) and fibrinogen levels $>200 \mathrm{mg} / \mathrm{dL}$ in children (110).

Use of fibrinogen concentrate to treat and prevent bleeding complications is reported in adults on ECMO $(113,114)$, but not children.

In summary, major bleeding is commonly seen in pediatric ECMO patients and hypofibrinogenemia may be encountered. Evidence supports regular monitoring, but appropriate triggers for supplementation with either plasma, cryoprecipitate or fibrinogen concentrate are unknown. Considering the high incidence of bleeding in children on ECMO, this area deserves more attention and research.

\section{Thrombolysis in the Pediatric Setting}

Venous and arterial thromboembolism are commonly encountered in the pediatric critical care setting (115). Treatment largely comprises targeted anticoagulation with intravenous heparin or low molecular weight heparin (115). Thrombolysis has a role in the treatment of life and organ threatening thrombosis and TPA is the most commonly studied and used $(116,117)$.

Systemic thrombolysis with tPA results in decreased fibrinogen levels, with many children developing significant hypofibrinogenemia and major bleeding (118). A retrospective study of 79 children treated with systemic tPA for thromboembolism, found that 56 experienced a drop in fibrinogen levels (median decrease $100 \mathrm{mg} / \mathrm{dL}$ ) and 10 children had fibrinogen levels $<100 \mathrm{mg} / \mathrm{dL}$. Overall, bleeding occurred in $54(68 \%)$ children, with $31(39 \%)$ requiring a red cell transfusion. Bleeding appeared to be seen in those who had 
the largest reductions in their fibrinogen levels following thrombolysis (118).

Due to substantial bleeding risk, pediatric thrombolysis guidelines advise that fibrinogen be maintained $>100$ $\mathrm{mg} / \mathrm{dL}$ during thrombolysis and major bleeding with hypofibrinogenemia be treated with cryoprecipitate $(116,117,119)$. Use of fibrinogen concentrate is reported in adult stroke patients with severe hypofibrinogenemia following treatment with $\mathrm{PA}$ (120).

\begin{abstract}
In summary, children receiving systemic $t P A$ are at significant risk of hypofibrinogenemia and bleeding complications. The evidence is too scarce to define a fibrinogen replacement trigger during or shortly after tPA. On the basis of retrospective data, general consensus advises to maintain fibrinogen levels of $>100 \mathrm{mg} / \mathrm{dL}$
\end{abstract}

\section{Acute Leukemia}

Hypofibrinogenemia may be seen in the context of pediatric leukemia associated DIC and is frequently encountered with acute promyelocytic leukemia (APML). APML cells express pro-coagulants including tissue factor and cancer procoagulant, as well as fibrinolytic proteins (plasminogen activators [t-PA and $\mathrm{u}-\mathrm{PA}$ ] and inhibitors [PAI-1] and their receptors [annexin II]) (121). As a result, APML is typically associated with a severe coagulopathy, consistent with a picture of DIC, excess hyperfibrinolysis, and marked hypofibrinogenemia (122). In children, hemorrhage is the main cause of early mortality (123). APML is a pediatric medical emergency necessitating urgent treatment with all-trans-retinoic acid (ATRA). ATRA induces terminal differentiation of malignant promyeloblasts to mature neutrophils (124). This cellular differentiation results in loss of the procoagulant and fibrinolytic properties of the APML cells, with improvement in bleeding symptoms and coagulopathy $(121,123)$.

There are no trials evaluating fibrinogen replacement triggers in APML. Major clinical trials advise that fibrinogen levels be monitored and treated with transfusions (124). The Pediatric International Consortium for Childhood APL (ICC- APL- 01) trial advises that fibrinogen levels $>150 \mathrm{mg} / \mathrm{dL}$ be maintained during the first 10 days of induction therapy or until resolution of any coagulopathy, using FFP (125). The Children's Oncology Group (COG) Study AAML0631 trial protocol advises that the fibrinogen be maintained $>100 \mathrm{mg} / \mathrm{dL}$ (126). The European LeukemiaNet guidelines suggest that following the diagnosis of APML immediate fibrinogen supplementation (FFP, fibrinogen, and or/cryoprecipitate) be implemented to maintain a fibrinogen concentration $>100-150 \mathrm{mg} / \mathrm{dL}$ and to continue through induction therapy until the coagulopathy resolves (127). Similar guidance is provided in the Canadian Blood Transfusion Guideline (42).

In summary, APML-associated hypofibrinogenemia carries a high risk of bleeding. The only definitive treatment is urgent treatment with ATRA, but in instances of clinically significant bleeding bridging with fibrinogen supplementation is advised on expert opinion. Most guidelines advise preemptive supplementation when fibrinogen levels fall $<100 \mathrm{mg} / \mathrm{dL}$, but the optimal product is unknown.

\section{Hemophagocytic Lymphohistiocytosis}

Hemophagocytic lymphohistiocytosis (HLH) is a rare, lifethreatening inflammatory syndrome with a peak incidence in infancy. It results from a dysregulated immune response that leads to pathological hyperactivation of NK cells, T lymphocytes, and macrophages (128). Hypofibrinogenemia $(<150 \mathrm{mg} / \mathrm{dL})$ is one of the eight criteria, included in the $2004 \mathrm{HLH}$ diagnostic criteria, where five out of eight criteria are required for diagnosis (129). Diagnostic workup for HLH in a child will include immune and genetic evaluation to measure proteins affects in familial HLH and viral serologies (EBV and CMV) to identify a common viral trigger for HLH (130).

It is not known, why hypofibrinogenemia develops in $\mathrm{HLH}$, proposed mechanisms include: hyperfibrinolysis secondary to DIC, decreased fibrinogen production secondary to hepatic macrophage infiltration, cytokine storm, and hyperfibrinogenolysis (131). A retrospective review of 117 adults with HLH, reported that fibrinogen levels $<200 \mathrm{mg} / \mathrm{dL}$ were associated with severe bleeding and independently associated with higher mortality (131). On the contrary, retrospective studies looking at predictors for mortality in children with HLH, did not identify hypofibrinogenemia as being a significant factor (132-134). Acute bleeding in the setting of hypofibrinogenemia and HLH may require fibrinogen supplementation (135). In general though, hypofibrinogenemia will only resolve with definitive HLH-treatment with etoposide and dexamethasone (130). Guidance around triggers for prophylactic fibrinogen supplementation in children was not found.

In summary, hypofibrinogenemia is one of the eight criteria used in making the diagnosis of HLH. Patients with HLH are at risk of bleeding. The only definitive treatment is $\mathrm{HLH}$ treatment with etoposide and dexamethasone. In cases of clinical bleeding and severe hypofibrinogenemia bridging with fibrinogen supplementation may be considered.

\section{NEONATES AND HYPOFIBRINOGENEMIA}

There are many age-dependent differences in fibrinogen and fibrinolysis in neonates, compared with older children. Regardless of the relative immaturity in the neonatal hemostatic system, in general neonates appear to have effective and balanced coagulation, and do not tend to bleed spontaneously (136).

In the critical care setting (NICU), neonates have different etiologies for acquired hypofibrinogenemia compared with older children. DIC in the neonate, most commonly occurs in the setting of perinatal asphyxia, but can be due to sepsis and perinatal acquired infections, respiratory distress syndrome and meconium aspiration $(14,137,138)$. Severe perinatal asphyxia can cause significant hypoxic brain injury and multi-organ failure, including hepatic damage $(139,140)$. Hypoxic hepatic damage can lead to reduced production of coagulation factors and hypofibrinogenemia (140). 
Rare, but potentially life-threatening causes of acquired hypofibrinogenemia in neonates include purpura fulminans due to congenital deficiency of protein C or protein S (141) and Kasabach-Merritt phenomenon (an acute consumptive coagulopathy specifically associated with two vascular tumors) (142). In Kasabach-Merritt phenomenon, a neonate may present with a rapidly growing tumor, with thrombocytopenia and severe hypofibrinogenemia, due to platelet sequestration, and fibrinogen consumption (142). There is a high risk of bleeding and management involves surgical or medical treatment of the tumor. If fibrinogen levels are $<100 \mathrm{mg} / \mathrm{dL}$ then FFP or cryoprecipitate is recommended, especially in the presence of bleeding (143).

The Italian neonatal transfusion guidelines provide definitions and guidance for fibrinogen replacement in neonates. They recommend observation rather than treatment in neonates with hypofibrinogenemia and no bleeding. But when active bleeding is present or a neonate is about to undergo an invasive procedure and the fibrinogen level is below the lower limit for gestational age, they recommend $5-10 \mathrm{~mL} / \mathrm{kg}$ of cryoprecipitate (38).

In summary, neonates tend to have lower fibrinogen levels without an increased bleeding risk. Therefore, most guidelines do not advise to correct asymptomatic hypofibrinogenemia. When an acquired, severe hypofibrinogenemia occurs and there is a high risk of bleeding, fibrinogen supplementation may be considered. The optimal fibrinogen replacement product in neonates is unknown.

\section{CURRENT KNOWLEDGE GAPS, CONTROVERSIES, AND AREAS FOR RESEARCH}

Although prophylactic and therapeutic use of cryoprecipitate and fibrinogen concentrate in both congenital and acquired hypofibrinogenemia has been widely adopted in a variety of pediatric critical care situations, there remain many uncertainties and controversies regarding fibrinogen replacement. Similar sentiments are echoed in the current adult literature (144-146).

The evidence base to support fibrinogen replacement in children is sparse or extrapolated from (also sparse) adult studies. We can only emphasize the need for more, well-designed, and sufficiently powered clinical trials in children. Considering the multiple national and international guidelines that exist about the use of fibrinogen in children, and the lack of consensus between guidelines, we see a medical need for international collaboration between guideline-writing groups.

There are number of questions that still need to be answered and may be proposed as areas for future research in neonates, including those preterm, infants, children, and adolescents with regard to clinical indications for fibrinogen supplementation.

Fibrinogen thresholds:

- What is the relationship between fibrinogen and bleeding in neonates and in children?
- What is the relationship between fibrinogen and bleeding in different clinical settings e.g., massive hemorrhage, trauma, $\mathrm{CPB}$, major surgical bleeding, ECMO, liver disease, DIC, and hyperfibrinolysis?

- What are the clinical indications for prophylactic fibrinogen replacement in neonates and children?

- What are the clinical indications for therapeutic fibrinogen replacement in children?

- What is the optimal fibrinogen level for neonates and children?

- undergoing high-risk surgical or invasive procedures?

- presenting with massive blood loss due to severe trauma?

- with other critical care conditions?

Prediction of hypofibrinogenemia-related bleeding and optimal treatment in children:

- How do we predict which neonates and children will bleed during or following surgery, and who are most likely to benefit from fibrinogen supplementation?

- How do we predict which neonates and children are most likely to benefit from fibrinogen supplement following trauma with massive blood loss or TBI?

- How do we predict which neonates and children are most likely to benefit from fibrinogen supplement in the context of sepsis, DIC, leukemia, and vascular tumors?

- Which fibrinogen product is the best choice in the different pediatric critical care clinical settings?

Clinical trials and guidelines:

- How do we increase the quality of clinical trials studying transfusion medicine in neonates and children?

- Can we come to an international consensus when there is a lack of evidence to reduce the variability of indications and triggers seen between national and international guidelines?

\section{CONCLUSIONS}

Critically ill children frequently experience bleeding events and hypofibrinogenemia is implicated in adult and pediatric settings as an important risk factor for bleeding. There remains considerable uncertainty in children of all ages around optimal fibrinogen levels and the best fibrinogen replacement strategies. Cryoprecipitate and fibrinogen concentrate are both given to prevent and treat bleeding due to hypofibrinogenemia, in spite of a sparse evidence base. Neonates and children continue to be under-represented or underpowered in clinical trials. Further evidence and RCTs in pediatric transfusion medicine are needed, so that, rather than extrapolate from adult studies or base practice on experience, best and evidence-based practice is delivered.

\section{AUTHOR CONTRIBUTIONS}

GC literature review and writing and editing article. $\mathrm{EH}$ reviewing content and editing article. All authors contributed to the article and approved the submitted version. 


\section{REFERENCES}

1. White LJ, Fredericks R, Mannarino CN, Janofsky S, Faustino EVS. Epidemiology of bleeding in critically ill children. J Pediatr. (2017) 184:114-9 e6. doi: 10.1016/j.jpeds.2017.01.026

2. Moorehead PC, Barrowman NJ, Cyr J, Ray J, Klaassen R, Menon K. A prospective study of the association between clinically significant bleeding in PICU patients and thrombocytopenia or prolonged coagulation times. Pediatr Crit Care Med. (2017) 18:e455-e62. doi: 10.1097/PCC.0000000000001281

3. Dalton HJ, Reeder R, Garcia-Filion P, Holubkov R, Berg RA, Zuppa A, et al. Factors associated with bleeding and thrombosis in children receiving extracorporeal membrane oxygenation. Am J Respir Crit Care Med. (2017) 196:762-71. doi: 10.1164/rccm.201609-1945OC

4. Velik-Salchner C, Haas T, Innerhofer P, Streif W, Nussbaumer W, Klingler A, et al. The effect of fibrinogen concentrate on thrombocytopenia. J Thromb Haemost. (2007) 5:1019-25. doi: 10.1111/j.1538-7836.2007.02481.x

5. Mosesson MW, Siebenlist KR, Meh DA. The structure and biological features of fibrinogen and fibrin. Ann N Y Acad Sci. (2001) 936:1130. doi: 10.1111/j.1749-6632.2001.tb03491.x

6. Niederwanger C, Bachler M, Hell T, Linhart C, Entenmann A, Balog $A$, et al. Inflammatory and coagulatory parameters linked to survival in critically ill children with sepsis. Ann Intensive Care. (2018) 8:111. doi: 10.1186/s13613-018-0457-8

7. Fries D, Martini WZ. Role of fibrinogen in trauma-induced coagulopathy. $\mathrm{Br}$ J Anaesth. (2010) 105:116-21. doi: 10.1093/bja/aeq161

8. Ranucci M, Bianchi P, Cotza M, Beccaris C, Silvetti S, Isgro G, et al. Fibrinogen levels and postoperative chest drain blood loss in low-weight $(<10 \mathrm{~kg})$ children undergoing cardiac surgery. Perfusion. (2019) 34:62936. doi: $10.1177 / 0267659119854246$

9. Faraoni D, Willems A, Savan V, Demanet H, De Ville A, Van der Linden P. Plasma fibrinogen concentration is correlated with postoperative blood loss in children undergoing cardiac surgery. a retrospective review. Eur J Anaesthesiol. (2014) 31:317-26. doi: 10.1097/EJA.0000000000000043

10. Nacoti M, Corbella D, Fazzi F, Rapido F, Bonanomi E. Coagulopathy and transfusion therapy in pediatric liver transplantation. World J Gastroenterol. (2016) 22:2005-23. doi: 10.3748/wjg.v22.i6.2005

11. Murray DJ, Olson J, Strauss R, Tinker JH. Coagulation changes during packed red cell replacement of major blood loss. Anesthesiology. (1988) 69:839-45. doi: 10.1097/00000542-198812000-00007

12. Hendrickson JE, Shaz BH, Pereira G, Atkins E, Johnson KK, Bao G, et al. Coagulopathy is prevalent and associated with adverse outcomes in transfused pediatric trauma patients. J Pediatr. (2012) 160:204-9 e3. doi: 10.1016/j.jpeds.2011.08.019

13. Doyle AJ, Hunt BJ. Current understanding of how extracorporeal membrane oxygenators activate haemostasis and other blood components. Front Med. (2018) 5:352. doi: 10.3389/fmed.2018.00352

14. Rajagopal R, Thachil J, Monagle P. Disseminated intravascular coagulation in paediatrics. Arch Dis Child. (2017) 102:18793. doi: 10.1136/archdischild-2016-311053

15. Solomon C, Pichlmaier U, Schoechl H, Hagl C, Raymondos K, Scheinichen $\mathrm{D}$, et al. Recovery of fibrinogen after administration of fibrinogen concentrate to patients with severe bleeding after cardiopulmonary bypass surgery. Br J Anaesth. (2010) 104:555-62. doi: 10.1093/bja/aeq058

16. Lee SH, Lee SM, Kim CS, Cho HS, Lee JH, Lee $\mathrm{CH}$, et al. Fibrinogen recovery and changes in fibrin-based clot firmness after cryoprecipitate administration in patients undergoing aortic surgery involving deep hypothermic circulatory arrest. Transfusion. (2014) 54:1379-87. doi: 10.1111/trf.12479

17. Galas FR, de Almeida JP, Fukushima JT, Vincent JL, Osawa EA, Zeferino $\mathrm{S}$, et al. Hemostatic effects of fibrinogen concentrate compared with cryoprecipitate in children after cardiac surgery: a randomized pilot trial. $J$ Thorac Cardiovasc Surg. (2014) 148:1647-55. doi: 10.1016/j.jtcvs.2014.04.029

18. Downey LA, Andrews J, Hedlin H, Kamra K, McKenzie ED, Hanley FL, et al. Fibrinogen concentrate as an alternative to cryoprecipitate in a postcardiopulmonary transfusion algorithm in infants undergoing cardiac surgery: a prospective randomized controlled trial. Anesth Analg. (2020) 130:740-51. doi: 10.1213/ANE.0000000000004384
19. Tinegate H, Allard S, Grant-Casey J, Hennem S, Kilner M, Rowley M, et al. Cryoprecipitate for transfusion: which patients receive it and why? A study of patterns of use across three regions in England. Transfus Med. (2012) 22:356-61. doi: 10.1111/j.1365-3148.2012.01158.x

20. Attard C, van der Straaten T, Karlaftis V, Monagle P, Ignjatovic V. Developmental hemostasis: age-specific differences in the levels of hemostatic proteins. J Thromb Haemost. (2013) 11:1850-4. doi: 10.1111/jth.12372

21. Ignjatovic $\mathrm{V}$, Ilhan $\mathrm{A}$, Monagle $\mathrm{P}$. Evidence for age-related differences in human fibrinogen. Blood Coagul Fibrinolysis. (2011) 22:110-7. doi: 10.1097/MBC.0b013e328343312f

22. Peyvandi F, Palla R, Menegatti M, Siboni SM, Halimeh S, Faeser B, et al. Coagulation factor activity and clinical bleeding severity in rare bleeding disorders: results from the European Network of Rare Bleeding Disorders. $J$ Thromb Haemost. (2012) 10:615-21. doi: 10.1111/j.1538-7836.2012.04653.x

23. Gosselin RC, Adcock D, Dorgalaleh A, Favaloro EJ, Lippi G, Pego JM, et al. International council for standardization in haematology recommendations for hemostasis critical values, tests, and reporting. Semin Thromb Hemost. (2019) 46:398-409. doi: 10.1055/s-0039-1697677

24. National Blood Authority (NBA). Patient Blood Management Guidelines: Module 6 - Neonates and Paediatrics. Canberra, ACT (2016).

25. New HV, Berryman J, Bolton-Maggs PH, Cantwell C, Chalmers EA, Davies $\mathrm{T}$, et al. Guidelines on transfusion for fetuses, neonates and older children. $\mathrm{Br}$ J Haematol. (2016) 175:784-828. doi: 10.1111/bjh.14233

26. Jensen NH, Stensballe J, Afshari A. Comparing efficacy and safety of fibrinogen concentrate to cryoprecipitate in bleeding patients: a systematic review. Acta Anaesthesiol Scand. (2016) 60:1033-42. doi: 10.1111/aas.12734

27. Fabes J, Brunskill SJ, Curry N, Doree C, Stanworth SJ. Pro-coagulant haemostatic factors for the prevention and treatment of bleeding in people without haemophilia. Cochrane Database Syst Rev. (2018) 12:CD010649. doi: 10.1002/14651858.CD010649.pub2

28. Cushing MM, Haas T. Fibrinogen concentrate for perioperative bleeding: what can we learn from the clinical trials? Transfusion. (2019) 59:32957. doi: $10.1111 / \operatorname{trf} .15437$

29. Haas T, Spielmann N, Restin T, Seifert B, Henze G, Obwegeser J, et al. Higher fibrinogen concentrations for reduction of transfusion requirements during major paediatric surgery: a prospective randomised controlled trial. $\mathrm{Br} \mathrm{J}$ Anaesth. (2015) 115:234-43. doi: 10.1093/bja/aev136

30. Chen W, Shen J, Zhang Y, Hu A, Liang J, Ma L, et al. A randomised controlled trial of fibrinogen concentrate during scoliosis surgery. Anaesthesia. (2020) 75:1476-81. doi: 10.1111/anae.15124

31. Machotta A, Huisman EJ, Appel IM, Luijnenburg SE, LopezYurda M, Cnossen MH, et al. Prophylactic fibrinogen concentrate administration in surgical correction of paediatric craniosynostosis: a double-blind placebo-controlled trial. Eur $J$ Anaesthesiol. (2020). doi: 10.1097/EJA.0000000000001332. [Epub ahead of print].

32. Siemens K, Hunt BJ, Harris J, Nyman AG, Parmar K, Tibby SM. Individualized, intraoperative dosing of fibrinogen concentrate for the prevention of bleeding in neonatal and infant cardiac surgery using cardiopulmonary bypass (FIBCON): a phase $1 \mathrm{~b} / 2 \mathrm{a}$ randomized controlled trial. Circ Cardiovasc Interv. (2020) 13:e009465. doi: 10.1161/CIRCINTERVENTIONS.120.009465

33. Cui Y, Hei F, Long C, Feng Z, Zhao J, Yan F, et al. Perioperative monitoring of thromboelastograph on blood protection and recovery for severely cyanotic patients undergoing complex cardiac surgery. Artif Organs. (2010) 34:95560. doi: 10.1111/j.1525-1594.2010.01148.x

34. Massoumi G, Mardani D, Mousavian SM, Bigdelian H. Comparison of the effect of fibrinogen concentrate with fresh frozen plasma (FFP) in management of hypofibrinogenemic bleeding after congenital cardiac surgeries: a clinical trial study. ARYA Atheroscler. (2018) 14:24853. doi: 10.22122 /arya.v14i6.1699

35. NCT02822599. Human Fibrinogen Concentrate in Pediatric Cardiac Surgery (RiaSTAP). Available online at: https://clinicaltrials.gov/ct2/show/ NCT02822599 (accessed September 26, 2020)

36. Goobie SM, Gallagher T, Gross I, Shander A. Society for the advancement of blood management administrative and clinical standards for patient blood management programs. 4th edition (pediatric version). Paediatr Anaesth. (2019) 29:231-6. doi: 10.1111/pan.13574 
37. Faraoni D, Meier J, New HV, Van der Linden PJ, Hunt BJ. Patient blood management for neonates and children undergoing cardiac surgery: 2019. NATA guidelines. J Cardiothorac Vasc Anesth. (2019) 33:324963. doi: 10.1053/j.jvca.2019.03.036

38. Girelli G, Antoncecchi S, Casadei AM, Del Vecchio A, Isernia P, Motta $\mathrm{M}$, et al. Recommendations for transfusion therapy in neonatology. Blood Transfus. (2015) 13:484-97. doi: 10.2450/2015.0113-15

39. National Institute of Health and Care Excellence (NICE). Blood Transfusion, London. (2015)

40. AABB. Technical Manual, 18th edition. Fung MK, editor. Bethesda, MD: AABB (2014)

41. Kozek-Langenecker SA, Ahmed AB, Afshari A, Albaladejo P, Aldecoa C, Barauskas G, et al. Management of severe perioperative bleeding: guidelines from the European Society of Anaesthesiology: first update 2016. Eur J Anaesthesiol. (2017) 34:332-95. doi: 10.1097/EJA.0000000000000630

42. Callum JL, Karkouti K, Liebermann L, Pendergrast JM, Robitaille N, Tinmouth A, et al. Bloody Easy 4. Ontario: Network ORBC (2016).

43. Polytrauma Guideline Update G. Level 3 guideline on the treatment of patients with severe/multiple injuries : AWMF Register-Nr. 012/019. Eur J Trauma Emerg Surg. (2018) 44(Suppl 1):3-271. doi: 10.1007/s00068-018-0922-y

44. Bundesärztekammer - German Medical Association. Cross-Sectional Guidelines for Therapy with Blood Components and Plasma Derivatives. (2014). 4th revised edition, 2014. Available online at: https://www. bundesaerztekammer.de/fileadmin/user_upload/downloads/pdf-Ordner/ WB/QLL_Haemotherapie-englisch.pdf (accessed September 21, 2020)

45. DeSimone RA, Nellis ME, Goel R, Haas T, Vasovic L, Cushing MM. Cryoprecipitate indications and patterns of use in the pediatric intensive care unit: inappropriate transfusions and lack of standardization. Transfusion. (2016) 56:1960-4. doi: 10.1111/trf.13649

46. Alport EC, Callum JL, Nahirniak S, Eurich B, Hume HA. Cryoprecipitate use in 25 Canadian hospitals: commonly used outside of the published guidelines. Transfusion. (2008) 48:2122-7. doi: 10.1111/j.1537-2995.2008.01826.x

47. Victorian Government Department of Health MV. Clinical Audit of Cryoprecipitate Use in Victorian, Tasmanian, and Australian Capital Territory Hospitals 2008. Melbourne, VIC (2010).

48. Peyvandi F, Duga S, Akhavan S, Mannucci PM. Rare coagulation deficiencies. Haemophilia. (2002) 8:308-21. doi: 10.1046/j.1365-2516.2002.00633.x

49. Casini A, Undas A, Palla R, Thachil J, de Moerloose P, Subcommittee on Factor X, et al. Diagnosis and classification of congenital fibrinogen disorders: communication from the SSC of the ISTH. J Thromb Haemost. (2018) 16:1887-90. doi: 10.1111/jth.14216

50. Acharya SS, Dimichele DM. Rare inherited disorders of fibrinogen. Haemophilia. (2008) 14:1151-8. doi: 10.1111/j.1365-2516.2008.01831.x

51. Neerman-Arbez M, Casini A. Clinical consequences and molecular bases of low fibrinogen levels. Int J Mol Sci. (2018) 19:192. doi: 10.3390/ijms19010192

52. de Moerloose P, Casini A, Neerman-Arbez M. Congenital fibrinogen disorders: an update. Semin Thromb Hemost. (2013) 39:585-95. doi: 10.1055/s-0033-1349222

53. World Federation of Hemophilia. World Federation of Hemophilia Statement on Cryoprecipitate for Treatment of Congenital Bleeding Disorders, Montréal, QC, (2019).

54. Peyvandi F, Haertel S, Knaub S, Mannucci PM. Incidence of bleeding symptoms in 100 patients with inherited afibrinogenemia or hypofibrinogenemia. J Thromb Haemost. (2006) 4:16347. doi: 10.1111/j.1538-7836.2006.02014.x

55. Mumford AD, Ackroyd S, Alikhan R, Bowles L, Chowdary P, Grainger J, et al. Guideline for the diagnosis and management of the rare coagulation disorders: a United Kingdom Haemophilia Centre Doctors' Organization guideline on behalf of the British Committee for Standards in Haematology. Br J Haematol. (2014) 167:304-26. doi: 10.1111/bjh.13058

56. Lisman T, Leebeek FW. Hemostatic alterations in liver disease: a review on pathophysiology, clinical consequences, and treatment. Dig Surg. (2007) 24:250-8. doi: 10.1159/000103655

57. D'Agata ID, Balistreri WF. Evaluation of liver disease in the pediatric patient. Pediatr Rev. (1999) 20:376-90; quiz 89-90. doi: 10.1542/pir.20-11-376
58. Drolz A, Horvatits T, Roedl K, Rutter K, Staufer K, Kneidinger N, et al. Coagulation parameters and major bleeding in critically ill patients with cirrhosis. Hepatology. (2016) 64:556-68. doi: 10.1002/hep.28628

59. Sabate A, Gutierrez R, Beltran J, Mellado P, Blasi A, Acosta F, et al. Impact of preemptive fibrinogen concentrate on transfusion requirements in liver transplantation: a multicenter, randomized, double-blind, placebocontrolled trial. Am J Transplant. (2016) 16:2421-9. doi: 10.1111/ajt.13752

60. European Association for the Study of the Liver, Wendon J, Cordoba J, Dhawan A, Larsen FS, Manns M, Samuel D, et al. EASL clinical practical guidelines on the management of acute (fulminant) liver failure. J Hepatol. (2017) 66:1047-81. doi: 10.1016/j.jhep.2016.12.003

61. O’Leary JG, Greenberg CS, Patton HM, Caldwell SH. AGA clinical practice update: coagulation in cirrhosis. Gastroenterology. (2019) 157:34-43 e1. doi: 10.1053/j.gastro.2019.03.070

62. Paugam-Burtz C, Levesque E, Louvet A, Thabut D, Amathieu R, Bureau C, et al. Management of liver failure in general intensive care unit. Anaesth Crit Care Pain Med. (2020) 39:143-61. doi: 10.1016/j.accpm.2019.06.014

63. Anand AC, Nandi B, Acharya SK, Arora A, Babu S, Batra Y, et al. Indian National Association for the Study of Liver Consensus Statement on Acute Liver Failure (Part-2): management of acute liver failure. J Clin Exp Hepatol. (2020) 10:477-517. doi: 10.1016/j.jceh.2020.04.011

64. Anand AC, Nandi B, Acharya SK, Arora A, Babu S, Batra Y, et al. Indian National Association for the Study of the Liver Consensus Statement on Acute Liver Failure (Part 1): epidemiology, pathogenesis, presentation and prognosis. J Clin Exp Hepatol. (2020) 10:339-76. doi: 10.1016/j.jceh.2020.04.012

65. Raffini L, Witmer C. Pediatric transplantation: managing bleeding. J Thromb Haemost. (2015) 13(Suppl. 1):S362-9. doi: 10.1111/jth.12913

66. Truelove E, Fielding AK, Hunt BJ. The coagulopathy and thrombotic risk associated with L-asparaginase treatment in adults with acute lymphoblastic leukaemia. Leukemia. (2013) 27:553-9. doi: 10.1038/leu.2012.290

67. Alqasim AMZ, Al-Hadithi RH, Al-Khalidi AN. Coagulopathic side effect of L-asparaginase on fibrinogen level in childhood acute lymphoblastic leukemia during induction phase. Hematol Oncol Stem Cell Ther. (2019) 12:67-9. doi: 10.1016/j.hemonc.2018.01.003

68. Hunault-Berger M, Chevallier P, Delain M, Bulabois CE, Bologna S, Bernard $M$, et al. Changes in antithrombin and fibrinogen levels during induction chemotherapy with L-asparaginase in adult patients with acute lymphoblastic leukemia or lymphoblastic lymphoma. use of supportive coagulation therapy and clinical outcome: the CAPELAL study. Haematologica. (2008) 93:1488-94. doi: 10.3324/haematol.12948

69. Pine AB, Lee EJ, Sekeres M, Steensma DP, Zelterman D, Prebet T, et al. Wide variations in blood product transfusion practices among providers who care for patients with acute leukemia in the United States. Transfusion. (2017) 57:289-95. doi: 10.1111/trf.13934

70. Astwood E, Vora A. Personal practice: how we manage the risk of bleeding and thrombosis in children and young adults with acute lymphoblastic leukaemia. Br J Haematol. (2011) 152:505-11. doi: 10.1111/j.1365-2141.2010.08446.x

71. Giordano P, Luciani M, Grassi M, De Leonardis F, Coletti V, Santoro N. Supplementation of fibrinogen concentrate in children with severe acquired hypofibrinogenaemia during chemotherapy for acute lymphoblastic leukaemia: our experience. Blood Transfus. (2014) $12 \mathrm{Suppl}$ 1:s156-7. doi: 10.2450/2013.0228-12

72. Pardo-González C A, Linares A, Torresc M. Transfusion therapy evidencebased recommendations for the pediatric cancer patient. Colombian J Anesthesiol. (2016) 44:151-60. doi: 10.1097/01819236-201644020-00013

73. Giordano P, Grassi M, Saracco P, Luciani M, Colombini A, Testi AM, et al. Human fibrinogen concentrate and fresh frozen plasma in the management of severe acquired hypofibrinogenemia in children with acute lymphoblastic leukemia: results of a retrospective survey. J Pediatr Hematol Oncol. (2019) 41:275-9. doi: 10.1097/MPH.0000000000001390

74. Diab YA, Wong EC, Luban NL. Massive transfusion in children and neonates. Br J Haematol. (2013) 161:15-26. doi: 10.1111/bjh.12247

75. Hiippala ST, Myllyla GJ, Vahtera EM. Hemostatic factors and replacement of major blood loss with plasma-poor red cell concentrates. Anesth Analg. (1995) 81:360-5. doi: 10.1213/00000539-199508000-00026 
76. Mazine A, Rached-D'Astous S, Ducruet T, Lacroix J, Poirier N, Pediatric Acute Lung I, et al. Blood transfusions after pediatric cardiac operations: a North American multicenter prospective study. Ann Thorac Surg. (2015) 100:671-7. doi: 10.1016/j.athoracsur.2015.04.033

77. Chan AK, Leaker M, Burrows FA, Williams WG, Gruenwald CE, Whyte L, et al. Coagulation and fibrinolytic profile of paediatric patients undergoing cardiopulmonary bypass. Thromb Haemost. (1997) 77:2707. doi: 10.1055/s-0038-1655952

78. Callum J, Farkouh ME, Scales DC, Heddle NM, Crowther M, Rao V, et al. Effect of fibrinogen concentrate vs cryoprecipitate on blood component transfusion after cardiac surgery: the fibres randomized clinical trial. JAMA. (2019) 322:1-11. doi: 10.1001/jama.2019.17312

79. Haas T, Cushing MM, Asmis LM. Comparison of the efficacy of two human fibrinogen concentrates to treat dilutional coagulopathy in vitro. Scand J Clin Lab Invest. (2018) 78:230-5. doi: 10.1080/00365513.2018.1437645

80. Keung CY, Smith KR, Savoia HF, Davidson AJ. An audit of transfusion of red blood cell units in pediatric anesthesia. Paediatr Anaesth. (2009) 19:320-8. doi: 10.1111/j.1460-9592.2009.02939.x

81. Rouette J, Trottier H, Ducruet T, Beaunoyer M, Lacroix J, Tucci M, et al. Red blood cell transfusion threshold in postsurgical pediatric intensive care patients: a randomized clinical trial. Ann Surg. (2010) 251:4217. doi: 10.1097/SLA.0b013e3181c5dc2e

82. Haas T, Fries D, Velik-Salchner C, Oswald E, Innerhofer P. Fibrinogen in craniosynostosis surgery. Anesth Analg. (2008) 106:725-31, table of contents. doi: 10.1213/ane.0b013e318163fb26

83. Kozek-Langenecker SA. Effects of hydroxyethyl starch solutions on hemostasis. Anesthesiology. (2005) 103:65460. doi: 10.1097/00000542-200509000-00031

84. Meier PM, Zurakowski D, Goobie SM, Proctor MR, Meara JG, Young VJ, et al. Multivariable predictors of substantial blood loss in children undergoing craniosynostosis repair: implications for risk stratification. Paediatr Anaesth. (2016) 26:960-9. doi: 10.1111/pan.12980

85. Kochanek KD, Murphy SL, Xu J, Arias E. Deaths: preliminary data for 2009. National Vital Statistics Reports. Hyattsville, MA: National Center for Health Statistics (2019) 4.

86. Ritchie H, Roser M. Causes of Death Our World in Data, Global Change Data Lab (2018).

87. Christiaans SC, Duhachek-Stapelman AL, Russell RT, Lisco SJ, Kerby JD, Pittet JF. Coagulopathy after severe pediatric trauma. Shock. (2014) 41:47690. doi: 10.1097/SHK.0000000000000151

88. Whittaker B, Christiaans SC, Altice JL, Chen MK, Bartolucci AA, Morgan CJ, et al. Early coagulopathy is an independent predictor of mortality in children after severe trauma. Shock. (2013) 39:4216. doi: 10.1097/SHK.0b013e31828e08cb

89. Leeper CM, Kutcher M, Nasr I, McKenna C, Billiar T, Neal M, et al. Acute traumatic coagulopathy in a critically injured pediatric population: definition, trend over time, and outcomes. J Trauma Acute Care Surg. (2016) 81:34-41. doi: 10.1097/TA.0000000000001002

90. Reed CR, Williamson H, Vatsaas C, Kamyszek R, Leraas HJ, Ray C, et al. Higher mortality in pediatric and adult trauma patients with traumatic coagulopathy, using age-adjusted diagnostic criteria. Surgery. (2019) 165:1108-15. doi: 10.1016/j.surg.2019.03.003

91. Driessen A, Wafaisade A, Lefering R, Migliorini F, Frohlich M, Arbab $\mathrm{D}$, et al. Mechanism, frequency, transfusion and outcome of severe trauma in coagulopathic paediatric patients. Eur J Trauma Emerg Surg. (2020) doi: 10.1007/s00068-020-01398-x. [Epub ahead of print].

92. McQuilten ZK, Wood EM, Bailey M, Cameron PA, Cooper DJ. Fibrinogen is an independent predictor of mortality in major trauma patients: a five-year statewide cohort study. Injury. (2017) 48:1074-81. doi: 10.1016/j.injury.2016.11.021

93. Bouzat P, Ageron FX, Charbit J, Bobbia X, Deras P, Nugues JBD, et al. Modelling the association between fibrinogen concentration on admission and mortality in patients with massive transfusion after severe trauma: an analysis of a large regional database. Scand J Trauma Resusc Emerg Med. (2018) 26:55. doi: 10.1186/s13049-018-0523-0

94. Murphy $\mathrm{CH}$, Spain DA, Shan H. Coagulopathy and transfusion ratios in pediatric trauma. J Trauma Acute Care Surg. (2020) 88:648-53. doi: 10.1097/TA.0000000000002609
95. Hagemo JS, Christiaans SC, Stanworth SJ, Brohi K, Johansson PI, Goslings JC, et al. Detection of acute traumatic coagulopathy and massive transfusion requirements by means of rotational thromboelastometry: an international prospective validation study. Crit Care. (2015) 19:97. doi: 10.1186/s13054-015-0823-y

96. Schochl H, Cotton B, Inaba K, Nienaber U, Fischer H, Voelckel W, et al. FIBTEM provides early prediction of massive transfusion in trauma. Crit Care. (2011) 15:R265. doi: 10.1186/cc10539

97. Leeper CM, Gaines BA. Viscoelastic hemostatic assays in the management of the pediatric trauma patient. Semin Pediatr Surg. (2017) 26:813. doi: 10.1053/j.sempedsurg.2017.01.004

98. Ziegler B, Schimke C, Marchet P, Stogermuller B, Schochl H, Solomon C. Severe pediatric blunt trauma-successful ROTEM-guided hemostatic therapy with fibrinogen concentrate and no administration of fresh frozen plasma or platelets. Clin Appl Thromb Hemost. (2013) 19:4539. doi: 10.1177/1076029612458149

99. Stinger HK, Spinella PC, Perkins JG, Grathwohl KW, Salinas J, Martini $\mathrm{WZ}$, et al. The ratio of fibrinogen to red cells transfused affects survival in casualties receiving massive transfusions at an army combat support hospital. J Trauma. (2008) 64(2 Suppl):S79-85; discussion S. doi: 10.1097/TA.0b013e318160a57b

100. Spahn DR, Bouillon B, Cerny V, Duranteau J, Filipescu D, Hunt $\mathrm{BJ}$, et al. The European guideline on management of major bleeding and coagulopathy following trauma: fifth edition. Crit Care. (2019) 23:98. doi: 10.1186/s13054-019-2347-3

101. NCT03508141. Fibrinogen Early in Severe Trauma Study Junior (FEISTY Jnr). (2020). Available online at: https://ClinicalTrials.gov/ show/NCT03508141 (accessed September 15, 2020)

102. Levi M, Toh CH, Thachil J, Watson HG. Guidelines for the diagnosis and management of disseminated intravascular coagulation. British committee for standards in haematology. Br J Haematol. (2009) 145:2433. doi: 10.1111/j.1365-2141.2009.07600.x

103. Wada H, Thachil J, Di Nisio M, Mathew P, Kurosawa S, Gando S, et al. Guidance for diagnosis and treatment of DIC from harmonization of the recommendations from three guidelines. J Thromb Haemost. (2013) 11:761-7. doi: $10.1111 /$ jth. 12155

104. Soundar EP, Jariwala P, Nguyen TC, Eldin KW, Teruya J. Evaluation of the international society on thrombosis and haemostasis and institutional diagnostic criteria of disseminated intravascular coagulation in pediatric patients. Am J Clin Pathol. (2013) 139:812-6. doi: 10.1309/AJCPO64IWNLYCVVB

105. Extracorporeal Life Support Organization. ECLS Registry Report International Summary, July 2020, Ann Arbor, MI (2020).

106. Hilal T, Mudd J, DeLoughery TG. Hemostatic complications associated with ventricular assist devices. Res Pract Thromb Haemost. (2019) 3:58998. doi: 10.1002/rth2.12226

107. Barbaro RP, Paden ML, Guner YS, Raman L, Ryerson LM, Alexander $P$, et al. Pediatric Extracorporeal life support organization registry international report 2016. ASAIO J. (2017) 63:456-63. doi: 10.1097/MAT.0000000000000603

108. Van Ommen CH, Neunert CE, Chitlur MB. Neonatal ECMO. Front Med. (2018) 5:289. doi: 10.3389/fmed.2018.00289

109. Doymaz S, Zinger M, Sweberg T. Risk factors associated with intracranial hemorrhage in neonates with persistent pulmonary hypertension on ECMO. J Intensive Care. (2015) 3:6. doi: 10.1186/s40560-015-0071-x

110. Hensch LA, Hui SR, Teruya J. Coagulation and bleeding management in pediatric extracorporeal membrane oxygenation: clinical scenarios and review. Front Med. (2018) 5:361. doi: 10.3389/fmed.2018.00361

111. Extracorporeal Life Support Organization (ELSO). Pediatric Cardiac Failure. Ann Arbor, MI: Arbor A, editor (2017).

112. Extracorporeal Life Support Organization (ELSO). Guidelines for Neonatal Respiratory Failure, Ann Arbor, MI (2017).

113. Tauber H, Streif W, Fritz J, Ott H, Weigel G, Loacker L, et al. Predicting transfusion requirements during extracorporeal membrane oxygenation. J Cardiothorac Vasc Anesth. (2016) 30:692-701. doi: 10.1053/j.jvca.2016. 01.009

114. Aubron C, DePuydt J, Belon F, Bailey M, Schmidt M, Sheldrake $\mathrm{J}$, et al. Predictive factors of bleeding events in adults undergoing 
extracorporeal membrane oxygenation. Ann Intensive Care. (2016) 6:97. doi: 10.1186/s13613-016-0196-7

115. Polikoff LA, Faustino EV. Venous thromboembolism in critically ill children. Curr Opin Pediatr. (2014) 26:286-91. doi: 10.1097/MOP.0000000000000084

116. Manco-Johnson MJ, Grabowski EF, Hellgreen M, Kemahli AS, Massicotte MP, Muntean W, et al. On behalf of the Scientific Subcommittee on Perinatal and Pediatric Thrombosis of the Scientific and Standardization Committee of the International Society of Thombosis and Haemostasis. Recommendations for tPA Thrombolysis in Children. Amsterdam. (2002) doi: 10.1055/s-0037-1613170

117. Monagle P, Chan AKC, Goldenberg NA, Ichord RN, Journeycake JM, Nowak-Gottl U, et al. Antithrombotic therapy in neonates and children: antithrombotic therapy and prevention of thrombosis, 9th ed: American college of chest physicians evidence-based clinical practice guidelines. Chest. (2012) 141(2 Suppl):e737S-801S. doi: 10.1378/chest.11-2308

118. Gupta AA, Leaker M, Andrew M, Massicotte P, Liu L, Benson LN, et al. Safety and outcomes of thrombolysis with tissue plasminogen activator for treatment of intravascular thrombosis in children. J Pediatr. (2001) 139:682-8. doi: 10.1067/mpd.2001.118428

119. Tarango C, Manco-Johnson MJ. Pediatric thrombolysis: a practical approach. Front Pediatr. (2017) 5:260. doi: 10.3389/fped.2017.00260

120. Vandelli L, Marietta M, Trenti T, Varani M, Bigliardi G, Rosafio F, et al. Fibrinogen concentrate replacement in ischemic stroke patients after recombinant tissue plasminogen activator treatment. Adv Clin Exp Med. (2019) 28:219-22. doi: 10.17219/acem/84936

121. Falanga A. Predicting APL lethal bleeding in the ATRA era. Blood. (2017) 129:1739-40. doi: 10.1182/blood-2017-02-763490

122. Mantha S, Tallman MS, Soff GA. What's new in the pathogenesis of the coagulopathy in acute promyelocytic leukemia? Curr Opin Hematol. (2016) 23:121-6. doi: 10.1097/MOH.0000000000000221

123. Abla O, Ribeiro RC. How I treat children and adolescents with acute promyelocytic leukaemia. $\mathrm{Br} J$ Haematol. (2014) 164:24-38. doi: 10.1111/bjh.12584

124. Breen KA, Grimwade D, Hunt BJ. The pathogenesis and management of the coagulopathy of acute promyelocytic leukaemia. Br J Haematol. (2012) 156:24-36. doi: 10.1111/j.1365-2141.2011.08922.x

125. Testi AM, Pession A, Diverio D, Grimwade D, Gibson B, de Azevedo AC, et al. Risk-adapted treatment of acute promyelocytic leukemia: results from the International Consortium for Childhood APL. Blood. (2018) 132:40512. doi: 10.1182/blood-2018-03-836528

126. Rajpurkar M, Alonzo TA, Wang YC, Gerbing RB, Gamis AS, Feusner $\mathrm{JH}$, et al. Risk markers for significant bleeding and thrombosis in pediatric acute promyelocytic Leukemia; report from the Children's Oncology Group Study AAML0631. J Pediatr Hematol Oncol. (2019) 41:515. doi: 10.1097/MPH.0000000000001280

127. Sanz MA, Grimwade D, Tallman MS, Lowenberg B, Fenaux P, Estey EH, et al. Management of acute promyelocytic leukemia: recommendations from an expert panel on behalf of the European LeukemiaNet. Blood. (2009) 113:1875-91. doi: 10.1182/blood-2008-04-1 50250

128. Al-Samkari H, Berliner N. Hemophagocytic lymphohistiocytosis. Annu Rev Pathol. (2018) 13:27-49. doi: 10.1146/annurev-pathol-020117-043625

129. Henter JI, Horne A, Arico M, Egeler RM, Filipovich AH, Imashuku $\mathrm{S}$, et al. HLH-2004: diagnostic and therapeutic guidelines for hemophagocytic lymphohistiocytosis. Pediatr Blood Cancer. (2007) 48:124-31. doi: 10.1002/pbc.21039

130. Jordan MB, Allen CE, Greenberg J, Henry M, Hermiston ML, Kumar A, et al. Challenges in the diagnosis of hemophagocytic lymphohistiocytosis: recommendations from the North American Consortium for Histiocytosis (NACHO). Pediatr Blood Cancer. (2019) 66:e27929. doi: 10.1002/pbc.27929

131. Valade S, Azoulay E, Galicier L, Boutboul D, Zafrani L, Stepanian $\mathrm{A}$, et al. Coagulation disorders and bleedings in critically ill patients with hemophagocytic lymphohistiocytosis. Medicine. (2015) 94:e1692. doi: 10.1097/MD.0000000000001692
132. Xu XJ, Wang HS, Ju XL, Xiao PF, Xiao Y, Xue HM, et al. Clinical presentation and outcome of pediatric patients with hemophagocytic lymphohistiocytosis in China: a retrospective multicenter study. Pediatr Blood Cancer. (2017) 64:e26264-e26270. doi: 10.1002/pbc.26264

133. Kaya Z, Bay A, Albayrak M, Kocak U, Yenicesu I, Gursel T. Prognostic factors and long-term outcome in 52 Turkish children with hemophagocytic lymphohistiocytosis. Pediatr Crit Care Med. (2015) 16:e165-73. doi: 10.1097/PCC.0000000000000449

134. Chen TY, Hsu MH, Kuo HC, Sheen JM, Cheng MC, Lin YJ. Outcome analysis of pediatric hemophagocytic lymphohistiocytosis. J Formos Med Assoc. (2020) 120:172-9. doi: 10.1016/j.jfma.2020.03.025

135. Jordan MB, Allen CE, Weitzman S, Filipovich AH, McClain KL. How i treat hemophagocytic lymphohistiocytosis. Blood. (2011) 118:404152. doi: 10.1182/blood-2011-03-278127

136. Chalmers EA. Neonatal coagulation problems. Arch Dis Child Fetal Neonatal Ed. (2004) 89:F475-8. doi: 10.1136/adc.2004.050096

137. Go H, Ohto H, Nollet KE, Kashiwabara N, Ogasawara K, Chishiki M, et al. Risk factors and treatments for disseminated intravascular coagulation in neonates. Ital J Pediatr. (2020) 46:54. doi: 10.1186/s13052-020-0815-7

138. Williams MD, Chalmers EA, Gibson BE, Haemostasis, Thrombosis Task Force BCfSiH. The investigation and management of neonatal haemostasis and thrombosis. Br J Haematol. (2002) 119:295-309. doi: 10.1046/j.1365-2141.2002.03674.x

139. Michniewicz B, Szpecht D, Sowinska A, Sibiak R, Szymankiewicz M, Gadzinowski J. Biomarkers in newborns with hypoxic-ischemic encephalopathy treated with therapeutic hypothermia. Childs Nerv Syst. (2020) 36:2981-8. doi: 10.1007/s00381-020-04645-Z

140. Choudhary M, Sharma D, Dabi D, Lamba M, Pandita A, Shastri S. Hepatic dysfunction in asphyxiated neonates: prospective case-controlled study. Clin Med Insights Pediatr. (2015) 9:1-6. doi: 10.4137/CMPed.S21426

141. Price VE, Ledingham DL, Krumpel A, Chan AK. Diagnosis and management of neonatal purpura fulminans. Semin Fetal Neonatal Med. (2011) 16:31822. doi: 10.1016/j.siny.2011.07.009

142. Mahajan P, Margolin J, Iacobas I. Kasabach-merritt phenomenon: classic presentation and management options. Clin Med Insights Blood Disord. (2017) 10:1179545X17699849. doi: 10.1177/1179545X17699849

143. Drolet BA, Trenor CC III, Brandao LR, Chiu YE, Chun RH, Dasgupta R, et al. Consensus-derived practice standards plan for complicated Kaposiform hemangioendothelioma. J Pediatr. (2013) 163:285-91. doi: 10.1016/j.jpeds.2013.03.080

144. Erdoes G, Koster A, Meesters MI, Ortmann E, Bolliger D, Baryshnikova E, et al. The role of fibrinogen and fibrinogen concentrate in cardiac surgery: an international consensus statement from the haemostasis and transfusion scientific subcommittee of the European association of cardiothoracic anaesthesiology. Anaesthesia. (2019) 74:1589-600. doi: 10.1111/anae.14842

145. Lunde J, Stensballe J, Wikkelso A, Johansen M, Afshari A. Fibrinogen concentrate for bleeding-a systematic review. Acta Anaesthesiol Scand. (2014) 58:1061-74. doi: 10.1111/aas.12370

146. Wong H, Curry N. Do we need cryoprecipitate in the era of fibrinogen concentrate and other specific factor replacement options? ISBT Sci Series. (2018) 13:23-38. doi: 10.1111/voxs.12376

Conflict of Interest: EH was an author of one of the RCTs discussed in this article.

The remaining author declares that the research was conducted in the absence of any commercial or financial relationships that could be construed as a potential conflict of interest.

Copyright (c) 2021 Crighton and Huisman. This is an open-access article distributed under the terms of the Creative Commons Attribution License (CC BY). The use, distribution or reproduction in other forums is permitted, provided the original author(s) and the copyright owner(s) are credited and that the original publication in this journal is cited, in accordance with accepted academic practice. No use, distribution or reproduction is permitted which does not comply with these terms. 